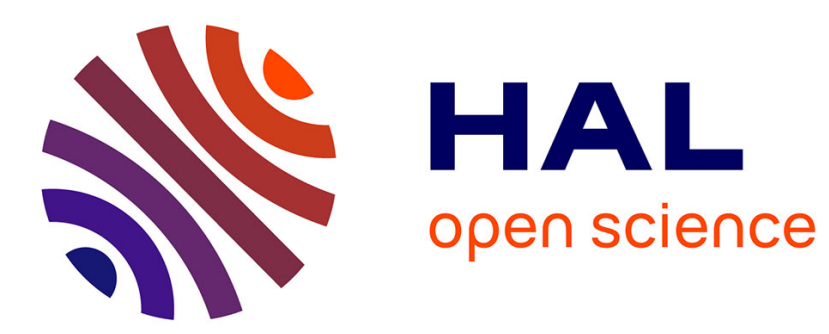

\title{
Role of ErbB/HER family of receptor tyrosine kinases in cholangiocyte biology
}

\author{
Anna Pellat, Javier Vaquero, Laura Fouassier
}

\section{To cite this version:}

Anna Pellat, Javier Vaquero, Laura Fouassier. Role of ErbB/HER family of receptor tyrosine kinases in cholangiocyte biology. Hepatology, 2018, 67 (2), pp.762-773. 10.1002/hep.29350 . hal-01789829

\section{HAL Id: hal-01789829 \\ https://hal.sorbonne-universite.fr/hal-01789829}

Submitted on 11 May 2018

HAL is a multi-disciplinary open access archive for the deposit and dissemination of scientific research documents, whether they are published or not. The documents may come from teaching and research institutions in France or abroad, or from public or private research centers.
L'archive ouverte pluridisciplinaire HAL, est destinée au dépôt et à la diffusion de documents scientifiques de niveau recherche, publiés ou non, émanant des établissements d'enseignement et de recherche français ou étrangers, des laboratoires publics ou privés. 


\title{
Role of ErbB/HER Family of Receptor Tyrosine Kinases in Cholangiocyte Biology
}

Anna Pellat, ${ }^{1}$ Javier Vaquero, ${ }^{1,2}$ and Laura Fouassier (DD ${ }^{1}$

\begin{abstract}
The ErbB/HER family comprises four distinct tyrosine kinase receptors, EGFR/ErbB1/HER1, ErbB2/HER2, ErbB3/ HER3, and ErbB4/HER4, which trigger intracellular signals at the origin of essential cellular functions, including differentiation, proliferation, survival, and migration. Epithelial cells, named cholangiocytes, that line intrahepatic and extrahepatic bile ducts, contribute substantially to biliary secretory functions and bile transport. Although ErbB receptors have been widely studied in cholangiocarcinoma (CCA), a malignancy of the biliary tract, knowledge of these receptors in biliary epithelium physiology and in non-malignant cholangiopathies is far from complete. Current knowledge suggests a role for epidermal growth factor receptor (EGFR) in cholangiocyte specification and proliferation, and in hepatocyte transdifferentiation into cholangiocytes during liver regeneration to restore biliary epithelium integrity. High expression and activation of EGFR and/or ErbB2 were recently demonstrated in biliary lithiasis and primary sclerosing cholangitis, two cholangiopathies regarded as risk factors for CCA. In CCA, ErbB receptors are frequently overexpressed, leading to tumor progression and low prognosis. Anti-ErbB therapies were efficient only in preclinical trials and have suggested the existence of resistance mechanisms with the need to identify predictive factors of therapy response. This review aims to compile the current knowledge on the functions of ErbB receptors in physiology and physiopathology of the biliary epithelium. (Hepatology 2017; 00:000-000).
\end{abstract}

\section{ErbB/HER Family}

The ErbB family of receptor tyrosine kinases comprises epidermal growth factor (EGF) receptor (EGFR; ErbB1/HER1), ErbB2 (HER2), ErbB3 (HER3), and ErbB4 (HER4; Fig. 1). These plasma membrane receptors are composed of an extracellular ligand-binding domain, a transmembrane domain, and an intracellular domain with a conserved tyrosine kinase (TK) domain, with the exception of ErbB3 which holds an inactive TK domain. They bind specific ligands belonging to the EGF family, with the exception of ErbB2 which has no known ligand. Thus, ErbB2 and ErbB3 are activated through heterodimerization with other family members. ErbB ligands are produced as transmembrane precursors and processed

Abbreviations: AKT, kinase B protein; Arf6, ADP-ribosylation factor 6; AV, ampulla of Vater; BAs, bile acids; BDL, bile duct-ligated; BPK, Balb/cbpk/bpk; CAF, cancer-associated fibroblasts; CCA, cholangiocarcinoma; COX-2: cyclooxygenase-2; HCC, hepatocellular carcinoma; iCCA, intrahepatic $C C A$; eCCA, extrahepatic CCA; EGF, epidermal growth factor; EGFR, EGF receptor; EMT, epithelial-mesenchymal transition; EP1, prostaglandin E2 receptor 1; ERK1/2, extracellular signal-regulated kinases 1 and 2; GB, gallbladder; HB-EGF, heparin-binding EGF-like growth factor; HGF, hepatocyte growth factor; HPC, hepatic progenitor cell; iCCA, intrahepatic CCA; IHC, immunohistochemistry; IL, interleukin; LPS, lipopolysaccharide; Mcl-1, myeloid cell leukemia sequence 1; MEK, mitogen-activated protein kinase kinase; MMP, metalloproteinase; mTOR, mammalian target of rapamycin; MUC5AC, mucin 5AC; NASH, nonalcoholic steato hepatitis; PI3K, phosphoinositide 3 kinase; PBC, primary biliary cholangitis; PCK, polycystic kidney; $P K D$, polycystic kidney disease; PLD, polycystic liver disease; PSC, primary sclerosing cholangitis; PG, prostaglandins; PGE2, prostaglandin E2; ROS, reactive oxygen species; S1PR2, shingosine 1-phosphate receptor 2; TACE, TNF- $\alpha$ converting enzyme; TNF $\alpha$, tumor necrosis factor $\alpha$; TGF $\alpha$, transforming growth factor $\alpha$; TGR5, G-protein-coupled bile acid receptor 5; TK, tyrosine kinase; TLR4, Toll-like receptor 4; TKI, tyrosine kinase intibitor; TME, tumor microenvironment; VEGFR, vascular endothelial growth factor receptor. 
by enzymes of the ADAM family, disintegrins, and metalloproteinases (MMPs), leading to the shedding of proligands and soluble growth factors release. ${ }^{(1)}$ Each ErbB receptor binds to specific ligands (Fig. 1). Upon ligand binding, homodimerization or heterodimerization of the receptor and subsequent phosphorylation of the TK domain occurs, allowing activation of intracellular signaling pathways ${ }^{(1)}$ (Fig. 1). These cytoplasmic pathways transmit the signal to the nucleus where many transcription factors undergo activity changes, initiating waves of transcription programs.

EGFR plays a fundamental role in normal physiology of epithelial cells. ${ }^{(1)}$ Other ErbB receptors are involved in cardiac and nervous development. ${ }^{(1)}$ Multiple studies have shown that ErbB receptors are also involved in numerous pathophysiological functions, including cell proliferation, differentiation, survival, adhesion, and migration. ${ }^{(1,2)}$

This review aims to give an overview of the current knowledge on the role of ErbB receptors in cholangiocyte biology during physiological events and pathological conditions. Finally, therapeutic options using antiErbB drugs will be discussed.

\section{ErbB Family in the Liver}

ErbB receptors have generated great interest since the discovery of the liver's involvement in EGF clearance. Early in the 1970s, it was shown that rat hepatocytes express EGFR and that the liver has the capacity to sequester EGF and secrete it into the bile. ${ }^{(3)} \mathrm{By}$ immunohistochemistry (IHC), EGFR is not detected or is barely detected in human hepatocytes, ${ }^{(4)}$ while it is detected in rodent hepatocytes at their sinusoidal and lateral surfaces, along with ErbB3. ${ }^{(5,6)}$ In cholangiocytes, EGFR is present at the basal membrane of rat $^{(7)}$ and human cholangiocytes. ${ }^{(8,9)}$ On the contrary, ErbB2 expression is detected in normal bile ducts only in one study, in large bile ducts. ${ }^{(10)}$ Both ErbB3 and
ErbB $4^{(8)}$ are barely or not detected in normal cholangiocytes of portal areas in human liver. Among ErbB ligands, transforming growth factor $\alpha(\mathrm{TGF} \alpha)$ is expressed by cholangiocytes. ${ }^{(9)}$

\section{ErbB Receptors in Cholangiocyte Physiology}

Cholangiocytes are a heterogeneous dynamic population of epithelial cells that line the bile ducts, known as the biliary tree. Their major physiological function lies in the modification of primary hepatic canalicular bile through both secretion and absorption processes. So far, no ErbB receptor has been involved in the regulation of cholangiocyte transport functions.

\section{CHOLANGIOCYTE SPECIFICATION}

During liver organogenesis, hepatic progenitor cells (HPCs), called hepatoblasts, differentiate into hepatocytes or cholangiocytes. ${ }^{(11)}$ Upon EGF treatment, the HPPL cell line, derived from mouse hepatoblasts, formed biliary cysts and developed epithelial polarity in three-dimensional culture with specific biliary markers, suggesting a role for EGF in biliary morphogenesis. ${ }^{(12)}$ In fetal liver, the Notch pathway plays a major role in the differentiation of hepatoblasts residing in the portal area into cholangiocytes, whereas in adult liver it controls the specification of HPC differentiation toward cholangiocytes and bile duct morphogenesis. ${ }^{(11)}$ Kitade et al., using clonal HPC lines generated from liverspecific EGFR knockout mice on a 3,5-diethoxycarbonyl-1,4-dihydrocollidine (DDC) diet, have shown that EGFR-mediated Notch1 signaling was essential for controlling commitment of HPC to biliary lineage. ${ }^{(13)}$ Indeed, deletion of EGFR in mouse HPC cells abolished biliary markers expression and

\section{ARTICLE INFORMATION:}

From the ${ }^{1}$ Sorbonne Universités, UPMC Université Paris 06, INSERM, Centre de Recherche Saint-Antoine (CRSA), Paris, France; and ${ }^{2}$ FONDATION ARC, Villejuif, France.

\section{ADDRESS CORRESPONDENCE AND REPRINT REQUESTS TO:}

Laura Fouassier, Ph.D.

INSERM UMR_S 893, Centre de Recherche Saint-Antoine (CRSA)

184 rue du Faubourg Saint-Antoine
75012 Paris, France

E-mail: laura.fouassier@inserm.fr

Tel: +33698774001 


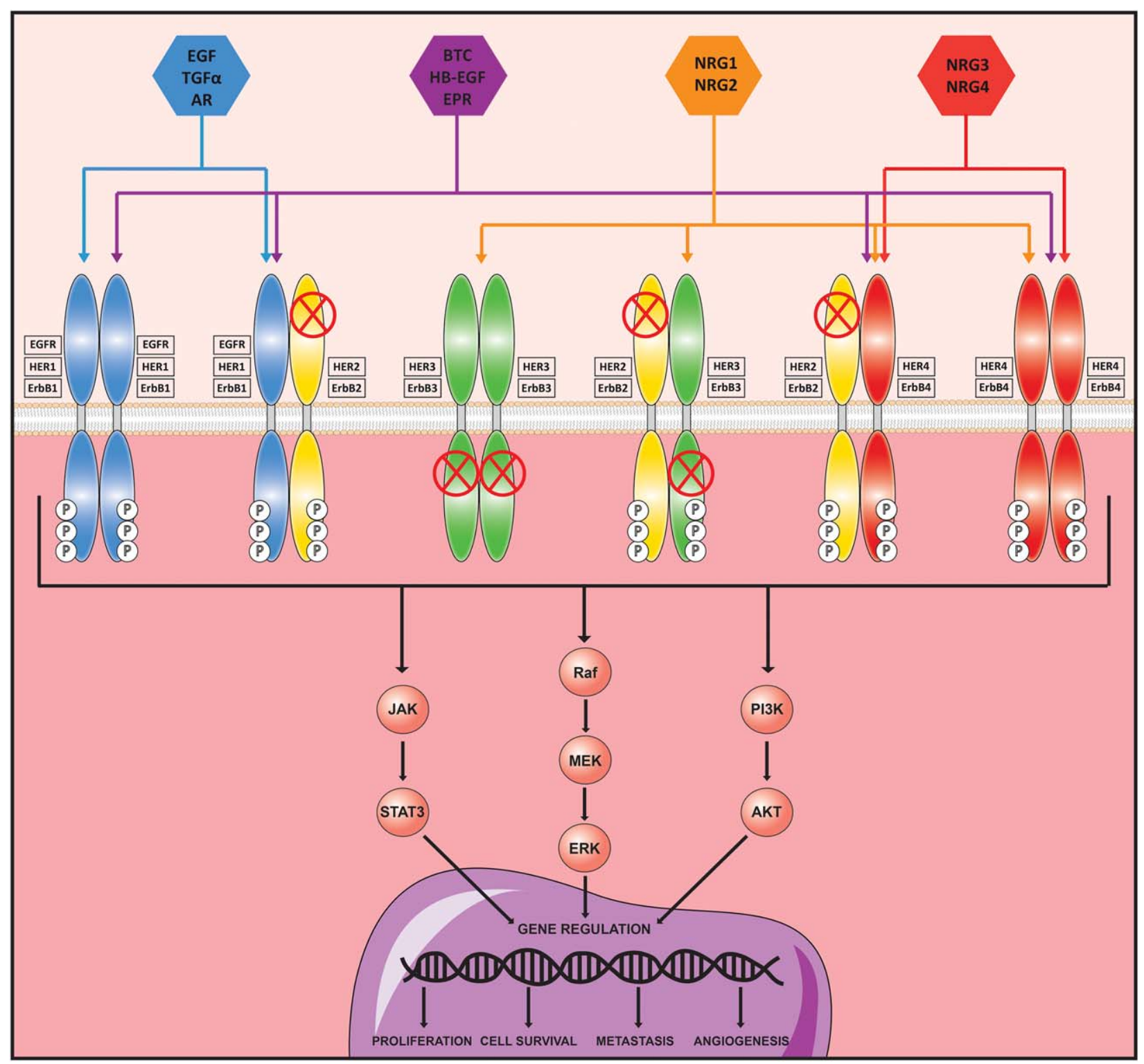

FIG. 1. ErbB family of receptor tyrosine kinases. The ErbB family includes four members, EGFR/ErbB1/HER1, ErbB2/HER2, ErbB3/HER3, and ErbB4/HER4. All ErbB receptors have in common an extracellular ligand-binding domain, a single membranespanning region, and a cytoplasmic protein TK domain. However, ErbB2 does not have any known ligand and naturally exists in a heterodimer form. Note also that ErbB3 lacks kinase activity, but can form heterodimers, especially with ErbB2, acting as an activating receptor. Their affinity for their ligands varies among the different ErbB members. Once activated and phosphorylated, they relay their signal through the main intracellular signaling pathways: JAK/STAT3, Raf/MEK/ERK, and PI3K/AKT. Abbreviations: AR, amphiregulin; BTC, betacellulin; EPR, epiregulin; JAK, janus kinase; NRG1-4, neurigulin 1-4; STAT3, signal transducer and activator of transcription 3 .

branching morphogenesis and strongly downregulated Notch1. Reintroduction of EGFR restored the branching phenotype and the expression of Notch1 and its target genes, Hes family BHLH transcription factor 1 (Hes1) and SRY (sex determining region Y)-box 9 (Sox9). The role of the EGFR/Notch1 pathway should be confirmed in human liver as well as its applicability during embryonic liver development. Recently, the EGFR/guanine nucleotide exchange factor 100 (GEF100)/ADP-ribosylation factor 6 (Arf6) signaling pathway has been envisaged as a regulator of intrahepatic biliary 
morphogenesis in a zebrafish model. ${ }^{(14)}$ Arf6 knockdown or pharmacological inhibition of EGFR in zebrafish embryo resulted in poor bile duct development. The deregulation of this pathway could notably be implicated in the pathogenesis of biliary atresia, a disease attributed to a defect in early bile duct development.

In regenerative medicine, cholangiocyte specification requires EGF, among other factors, to generate cholangiocytes from human pluripotent stem cells. ${ }^{(15,16)}$ In Ogawa et al.'s study, Notch signaling is first activated in the hepatoblast population to induce the initial stages of cholangiocyte development. Then, the combination of growth factors, including EGF, allows early bile duct morphogenesis. ${ }^{(16)}$ However, EGF's precise role remains unclear, and lineage tracing studies evaluating the role of EGFR in this process are still needed.

\section{LIVER REGENERATION}

Liver regeneration is a complex process involving many mechanisms and growth factors that, together with their receptors, regulate proliferation. One property of regenerating liver is the ability of mature adult hepatocytes and cholangiocytes to interchange their phenotypes when needed. If a drastic loss of hepatocytes occurs, cholangiocytes can transdifferentiate into hepatocytes to regenerate the liver parenchyma. ${ }^{(17)}$ Conversely, hepatocytes can contribute to biliary regeneration in case of acute hepatobiliary or chronic biliary injuries in order to restore the biliary epithelium's structure and function. ${ }^{(18)}$ Although the involvement of an ErbB-dependent signaling has not been reported in the conversion of cholangiocyte into hepatocyte, EGFR may contribute to the conversion of hepatocyte into cholangiocyte-like phenotype. ${ }^{(19)}$ In rat organoid cultures, EGF, through kinase B protein (AKT)-independent phosphoinositide 3 kinase (PI3K) activation, was the only growth factor, along with hepatocyte growth factor (HGF), capable of promoting hepatocyte transdifferentiation into cholangiocytes. Gene array analysis identified the biliary markers cytokeratin 19, amphiregulin, and secretin receptors among the up-regulated genes. ${ }^{(19)}$ The role of ErbB receptors in cholangiocyte proliferation during liver regeneration is undetermined because models of cholangiocyte-specific EGFR knockout are missing.

\section{ErbB Receptors in Non-malignant Cholangiopathies}

Cholangiocytes are targets of a number of chronic biliary diseases also known as cholangiopathies. Main primary cholangiopathies regroup autoimmune cholangitis, primary sclerosing cholangitis (PSC), primary biliary cholangitis (PBC; formerly primary biliary cirrhosis), and biliary atresia. ${ }^{(20)}$ Rare genetic diseases can also affect the biliary tree, such as cystic fibrosis, polycystic liver disease (PLD), and Caroli's disease. ${ }^{(20)}$ Finally, chronic hepatolithiasis is a frequent secondary sclerosing cholangitis.

\section{ROLE OF ERBB IN CHOLANGIOCY'TES}

Many studies imply that under the combination of endogenous and exogenous factors, cholangiocytes become reactive with secretion of proinflammatory molecules, leading to chronic inflammation of bile ducts, cholestasis, biliary epithelial cell proliferation, fibrosis, and malignant transformation. ${ }^{(20)}$ Therefore, in case of injury, cholangiocyte proliferation is at the crossroads of liver reparation and disease development. Cholangiocytes, virtually quiescent, maintain mitotic capability throughout adult life. This pathological proliferation of cholangiocytes has been studied in order to understand the link between biliary injury, cholangiopathies, and, later, cholangiocarcinoma (CCA). EGFR, ErbB2, and some of their ligands, have been implicated in these processes. EGF is a key mitogenic component for both murine and human cholangiocytes, ${ }^{(21,22)}$ for hyperplastic bile ductular epithelial cells isolated from cholestatic liver (i.e., bile duct-ligated [BDL] mice and BDL/furan rat models), and is involved in ductal morphogenesis, ${ }^{(23)}$ and cell-cell junction integrity. ${ }^{(24,25)}$

\section{ERBB EXPRESSION IN CHOLANGIOPATHIES}

\section{Hepatolithiasis}

EGFR and ErbB2 are frequently expressed in tissue samples with hepatolithiasis. ${ }^{(26-28)}$ Immunohistochemical (IHC) analysis of human gallbladder (GB) tissues with gallstones showed overexpression of mucin $5 \mathrm{AC}$ (MUC5AC) associated with neutrophil infiltration 
and increased expression of EGFR and tumor necrosis factor $\alpha(\mathrm{TNF} \alpha) .{ }^{(26)}$ In vitro, EGF or TGF $\alpha$, combined with $\mathrm{TNF} \alpha$, induced an overexpression of EGFR resulting in MUC5AC overproduction. ${ }^{(26)}$ In addition, bacterial infections and bile flow retardation contribute to stone formation and recurrence in hepatolithiasis. $^{(29)}$ Lipopolysaccharide (LPS) increases MUC5AC expression in cholangiocytes by interacting with its receptor Toll-like receptor 4 (TLR4), which increases ADAM17-dependent cleavage of TGF $\alpha$, promoting activation of EGFR. ${ }^{(29)}$ Accordingly, increased expression levels of ErbB ligands have been detected in BDL models. ${ }^{(30)}$ Finally, epithelialmesenchymal transition (EMT), a reversible process by which epithelial cells acquire mesenchymal features, is involved in the development and progression of fibrosis, such as hepatolithiasis-induced biliary fibrosis. ${ }^{(31)}$ IHC analysis of human hepatolithiasis showed a strong expression of EGFR in the ductular epithelium that correlated with increased EMT-related protein expression, ${ }^{(31)}$ suggesting a link between EGFR and EMT in nontumor cholangiocytes. However, EMT pathophysiological significance in hepatolithiasis remains unclear. Given that cholangiocytes in cholangiopathies do not undergo EMT, but rather acquire some mesenchymal properties as part of a "reactive" phenotype, ${ }^{(32)}$ EGFR could take part in the regulation of this reactive phenotype.

\section{PSC}

Cholangiocytes from human PSC samples exhibited increased phospho-EGFR compared to normal livers and other liver diseases. ${ }^{(33)}$ In vivo, hepatocyte/cholangiocyte-specific ablation of EGFR in Mdr2 knockout mice $\left(M d r 2^{-/}\right)$, led to an aggravation of liver fibrosis, along with a more prominent cholangiocyte proliferation compared to $M d r 2^{-/}$control mice, suggesting that cholangiocyte proliferation is independent of EGFR. ${ }^{(34)}$ ErbB2 was overexpressed in a small cohort of human samples of PSC, suggesting that it could represent an early dysfunctional event linked to human cholangiocarcinogenesis in this disease. ${ }^{(35)}$ Further studies should be pursued to identify whether ErbB members participate in cholangiocyte proliferation in PSC and whether ErbB expression/activation is predictive of CCA occurrence.

\section{PLD}

PLD and Caroli's disease are genetic diseases responsible for the formation of cysts along the biliary tract. IHC analysis of human adult biliary cysts failed to show signs of cholangiocyte proliferation, but revealed strong expression of EGFR in cyst epithelia and variable expression of ErbB2. This study suggested that cyst formation happens in a non-proliferative way despite the expression of ErbB receptors. ${ }^{(36)}$ On the other hand, in vitro, cholangiocytes isolated from the Balb/c-bpk/bpk (BPK) mice or polycystic kidney $(\mathrm{PCK})$ rat demonstrated an increased sensitivity to the proliferative effect of EGF, ${ }^{(22,37)}$ suggesting a role for EGFR in biliary epithelial hyperplasia and duct ectasia. Therefore, the EGFR tyrosine kinase inhibitors (TKIs), for example, EKI-785 and gefitinib, were expected to reduce biliary cyst formation. They were efficient in reducing biliary ductal ectasia in BPK mice and proliferation of cholangiocytes isolated from the PCK rat. ${ }^{(22,38)}$ However, EKI-785 could not prevent in vivo the development of cystic liver disease in the PCK rat. ${ }^{(39)}$ Further studies are needed to conclude definitively on the role of EGFR in cyst formation in PLD.

\section{ErbB Receptors in CCA}

CCA is a heterogeneous group of malignant tumors that emerge along the biliary tree. CCA is often diagnosed at advanced stages and can rarely be treated by surgery, although it is the only curative treatment. For unresectable patients, the treatment is chemotherapy with a combination of gemcitabine and a platinum salt. $^{(40)}$

Several studies have addressed the molecular and cellular mechanisms underlying the potential role of ErbB receptors in CCA physiopathology. An integrative genomic analysis on 149 intrahepatic CCA (iCCA) human samples identified two different classes: proliferation and inflammation. ${ }^{(41)}$ The proliferation class (62\% of samples) was associated with worse outcome and $32 \%$ of patients had an EGFR overexpression, ${ }^{(41)}$ which suggests that EGFR is a low prognostic factor in CCA.

\section{EGFR}

\section{Expression, Mutation and Amplification}

Many studies have reported the expression of EGFR by IHC analyses in human CCA samples with a great variability (from 0\% to 100\%; Supporting Table S1). Some have shown that the expression of EGFR 


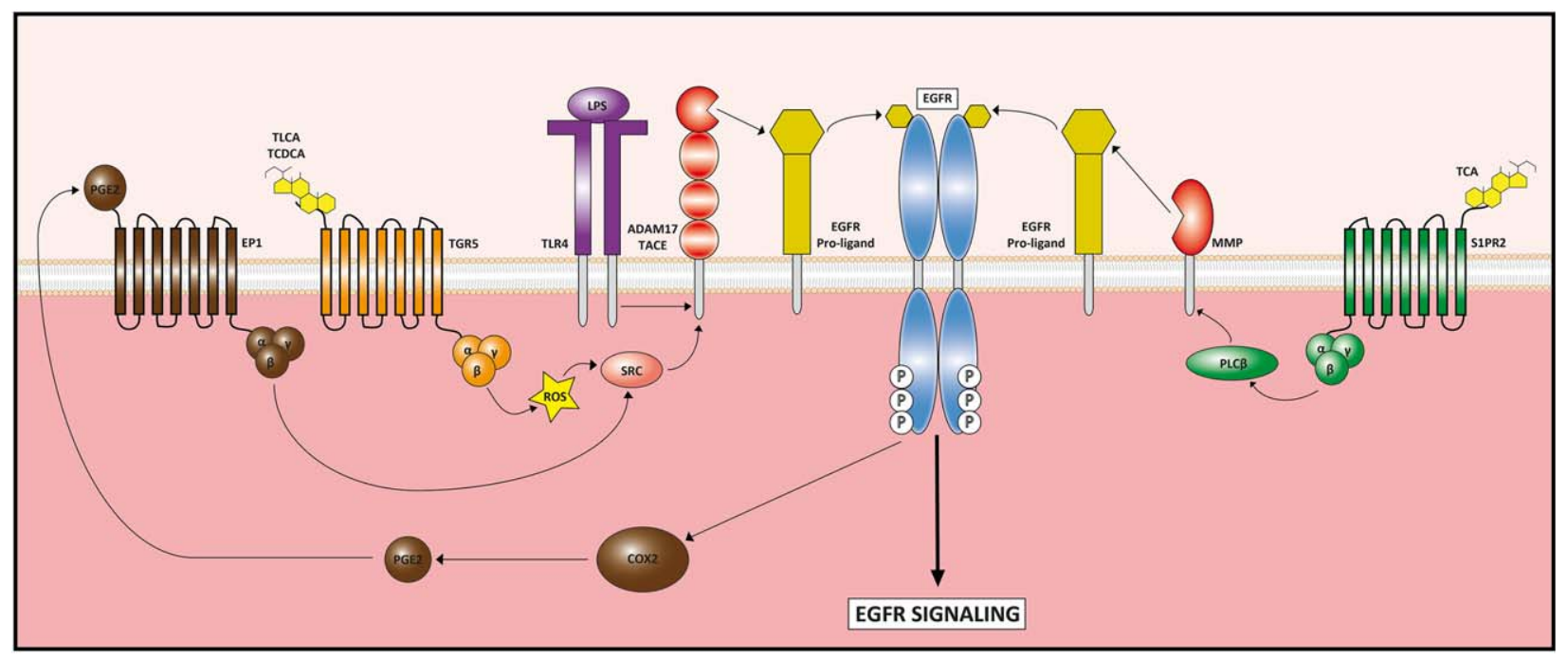

FIG. 2. Mechanisms of indirect EGFR activation by bile acids (TLCA, TCDCA, and TCA), LPS, and PGE2. The three compounds are able to stimulate the cleavage of EGFR proligands to produce mature EGFR ligands that, in turn, increase EGFR activation and signaling. Bile acid activation of TGR5 and S1PR2 leads to EGFR proligand cleavage by ADAM17/TACE and MMPs thorough the activation of SRC and PLC $\beta$, respectively. Similarly, TLR4 activation by LPS promotes ADAM17/TACE activity by unknown mechanisms. In addition, EGFR activation induces COX2 signaling, which increases PGE2 production. Then, PGE2 activates EP1 receptor that, in turn, induces SRC signaling to activate EGFR proligand cleavage by ADAM17/TACE. Abbreviations: ADAM17, ADAM metallopeptidase domain 17; PLC $\beta$, phospholipase C-beta; TCA, taurocholic acid; TCDCA, taurochenodeoxycholic acid; TLCA, taurolithocholic acid.

was associated with clinicopathological and poor prognostic features.

EGFR mutations are detected in CCA, in $0 \%-15 \%$ of cases, primarily in exons 18-21 coding for the EGFR TK domain (Supporting Table S2). Among mutations encountered, the T790M mutation in exon 20 was reported in few patients with CCA. This mutation has been involved in acquired resistance to EGFR TKI in other cancers. Furthermore, EGFR mutations were more frequent in CCA developed on chronic advanced liver disease. ${ }^{(42)}$ EGFR mutations also turned out to be low prognostic markers in CCA. ${ }^{(41)}$ Genetic polymorphisms of EGFR have been reported in CCA with a higher frequency than in hepatolithiasis, suggesting an association between EGFR polymorphisms and susceptibility of CCA and patient survival. ${ }^{(43)}$ Finally, EGFR amplification is rarely detected in CCA (Supporting Table S1).

\section{Role of EGFR in CCA Physiopathology}

EGFR regulates proliferation, ${ }^{(4)}$ migration, and invasion $^{(45)}$ of CCA cells. Upon EGF stimulation, CCA cells exhibit sustained EGFR activation attributed to defective receptor internalization, which leads to proliferation. ${ }^{(44)}$ Moreover, sustained activation of EGFR, caused by the deregulation of NHERF1/ EBP50, led to EMT-associated features, migration, and invasion. ${ }^{(45,46)}$

EGFR signaling is complex because EGFR can be activated indirectly by various compounds known to participate in the pathogenesis of CCA, such as bile acids (BAs). BAs increased cellular myeloid cell leukemia sequence 1 ( $\mathrm{Mcl}-1)$ protein levels, a potent antiapoptotic protein from the B-cell lymphoma 2 (Bcl-2) family, by inhibiting Mcl-1 degradation through the EGFR/Raf-1 signaling pathway ${ }^{(47)}$ and the production of cyclooxygenase-2 (COX-2) through the EGFR/ mitogen-activated protein kinase (MAPK) signaling pathway. ${ }^{(47)}$ EGFR activation by BAs occurred through a TGF $\alpha$-dependent mechanism involving MMP activity as a requisite for TGF $\alpha$ membrane release $^{(48)}$ (Fig. 2). More recently, it was reported that conjugated BAs promoted the invasive growth of CCA through activation of sphingosine 1-phosphate receptor 2 (S1PR2; Fig. 2) followed by activation of the EGFR/extracellular signal-regulated kinases 1 and 2 (ERK1/2) signaling pathway. ${ }^{(4)}$ Finally, it was shown, in BDL mice, that BAs trigger cholangiocyte proliferation after binding to their $\mathrm{G}$-protein-coupled 
bile acid receptor 1 (Gpbar-1 or TGR5; Fig. 2) and activation of the EGFR/ERK1/2 pathway. ${ }^{(50)}$ TGR5 was also found overexpressed in human CCA tissue, suggesting that the BAs/TGR5/EGFR pathway identified in nonmalignant cholangiocytes could also play a role in biliary malignancies. ${ }^{(50)}$

The other major component engaged in EGFR transactivation is the $\mathrm{COX}$-2-derived prostaglandin E2 (PGE2; Fig. 2). In CCA, COX-2 and PGE2 are overexpressed and display mitogenic, antiapoptotic, and angiogenic functions. ${ }^{(51)}$ PGE2 released into the extracellular space binds to its receptor, prostaglandin E2 receptor 1 (EP1), a G-protein-coupled receptor, leading to EGFR/AKT axis activation that triggers CCA cell proliferation and invasion. ${ }^{(52)}$ To add a higher level of complexity, activation of EGFR by its prototypal ligand, EGF, causes increased production of COX-2 and PGE2, thereby generating a vicious cycle of COX-2/PGE2/EP1/EGFR signaling ${ }^{(52)}$ (Fig. 2). LPS, also by interacting with its receptor TLR4, is at the origin of EGFR transactivation (Fig. 2). By activating EGFR through TNF- $\alpha$ converting enzyme (TACE)-dependent TGF $\alpha$ release, LPS increases production of COX-2 and PGE2 that in turn creates a second wave of phosphorylation of EGFR and ERK1/ 2 , triggering a feedback loop. ${ }^{(53)}$

Interleukin (IL)-6 is another proinflammatory cytokine that contributes to chronic biliary inflammation and CCA carcinogenesis. Overexpression of IL-6 decreased EGFR promoter methylation, resulting in an increase of EGFR expression in CCA cells. ${ }^{(54)}$ Finally, resistance to oxidative stress leads to abnormal proliferation and transformation. $\mathrm{H}_{2} \mathrm{O}_{2}$-induced oxidative stress activated the MAPK-activated protein kinase 2 (MK2)-dependent transduction pathway, which itself activated the heparin-binding EGF-like growth factor (HB-EGF)/EGFR axis, therefore allowing cells to survive in this oxidative environment. ${ }^{(55)}$

Altogether, EGFR acts as a hub by integrating multiple external information, including its own ligands and other compounds such as BAs, bacterial products, and inflammatory factors, promoting genesis and progression of CCA.

\section{ERBB2}

ErbB2 expression levels vary from $0 \%$ to $82 \%$ in human CCA specimens (Supporting Table S3). Some studies have investigated ErbB2 gene amplification and found results varying from $0 \%$ to $100 \%$ of samples, depending on methods and localization of the malignancy along the biliary tree. Results on the link between ErbB2 expression and clinicopathological and prognostic factors were also discordant, although no study has shown any impact on survival (Supporting Table S3). In addition, ErbB2 mutation in CCA remains a marginal event (Supporting Table S2).

Transgenic mice specifically overexpressing ErbB2 in epithelial tissues showed development of GB carcinomas and tumors all along the biliary tract. ${ }^{(56)}$ Likely, transplantation of BDEneu cells (an immortalized rat cholangiocyte cell line overexpressing ErbB2/neu) in the rat biliary tract resulted in the development of CCA-like tumors. ${ }^{(57)}$ The BDEneu cells showed an up-regulation of COX-2. ${ }^{(57)}$ and combined therapies with anti-COX2 and anti-ErbB2 inhibit cell growth. ${ }^{(58)}$ A study in rodents also showed up-regulation of COX-2 associated with overexpression of ErbB2/EGFR heterodimers in GB epithelium. ${ }^{(56)}$ These results as well as immunostaining observations of COX-2 and ErbB2 in human CCA tissues ${ }^{(35)}$ suggest that ErbB2 might play a key role in regulating $\mathrm{COX}-2$ expression in precancerous and neoplastic cholangiocytes. Conjugated BAs increased proliferation of CCA cells through the activation of EGFR/ErbB2 heterodimer. ${ }^{(59)}$

\section{ERBB3 AND ERBB4}

Expression of ErbB3 was observed in 11.8\%-39\% of CCA cases in various studies and was associated with poorly differentiated tumors and decreased survival (Supporting Table S4). ErbB3 mutations were identified in $11.8 \%$ of GB carcinoma samples, with ErbB3 being the most frequent ErbB mutated receptor (Supporting Table S2). Fluorescent in situ hybridization analysis demonstrated a gene amplification of HER3 in 23\% of CCA samples. ErbB4 was expressed in 39.5\%-63.1\% of CCA samples (Supporting Table S5). Its expression was related directly to lymph node metastasis and to a better survival in EGFR-negative iCCA (Supporting Table S5). So far, one missense mutation in HER4 has been reported in iCCA (Supporting Table S2). Although both receptors are expressed in CCA, the pathophysiological mechanisms underlying their roles in CCA are still unknown.

\section{ROLE OF TUMOR MICROENVIRONMENT IN ERBB SIGNALING}

Increasing evidence indicates that the tumor microenvironment (TME), with its diversity of cell types 
and extracellular components, does not simply provide an anatomically supporting tissue, but also contributes to cancer progression and chemoresistance. At the cellular level, the TME in CCA is abundantly composed of cancer-associated fibroblasts (CAFs), ${ }^{(40)}$ suggesting a fundamental role for these cells in CCA biology, which has been confirmed by several studies, including ours. ${ }^{(40,60)}$ We showed that CAFs from CCA expressed EGFR ligands, including HB-EGF, which promote $\mathrm{CCA}$ cell invasion through activation of the HB-EGF/EGFR axis. ${ }^{(60)}$

\section{Anti-ErbB Therapies in Cholangiopathies}

There are two major classes of anti-ErbB therapies (Supporting Table S6): monoclonal antibodies, which block ligand binding, and TKI, which target the catalytic domain of the receptor.

\section{IN NON-MALIGNANT CHOLANGIOPATHIES}

EGFR TKIs have been tested in models of PKD/ PLD. They were efficient in the kidney, ${ }^{(61)}$ but results in the liver were contradictory. As mentioned, EGFR TKIs were efficient in reducing biliary ductal ectasia in BPK mice, ${ }^{(38)}$ but could not prevent the development of cystic liver disease in the PCK rat. ${ }^{(39)}$ Further studies are needed to verify these results.

In a rat model of proliferative cholangitis, treatment with anti-EGFR reduced biliary epithelium hyperplasia, fibrosis, and hyperplasia of peribiliary glands. ${ }^{(62)}$ Similarly, in the BDL model, erlotinib significantly reduced fibrosis. ${ }^{(63)}$ To date, there are no clinical trials with these therapies.

\section{IN MALIGNANT CHOLANGIOPATHIES}

\section{Preclinical Assays}

Treatment of CCA cells with anti-EGFR therapies (gefitinib or cetuximab) inhibits cell growth ${ }^{(44,64)}$ and induces G1-phase arrest and apoptosis. ${ }^{(64,65)}$ ErbB2 inhibitors alone were also effective in vitro in CCA cell lines. ${ }^{(66)}$ Moreover, EGFR/ErbB2 combined inhibition was more efficient than either anti-EGFR or anti-ErbB2 alone. ${ }^{(66)}$ Anti-ErbB therapies have also been tested combined with other types of treatments (chemotherapy or non-ErbB-targeted therapies). Gefitinib/erlotinib and lapatinib (dual EGFR/ErbB2) had antiproliferative effects in CCA cell lines when combined with gemcitabine. ${ }^{(67)} \mathrm{Com}-$ bination of anti-EGFR therapies with other targeted therapies, such as mitogen-activated protein kinase kinase $(\mathrm{MEK}){ }^{(68)}$ mammalian target of rapamycin (mTOR), ${ }^{(69)}$ or vascular endothelial growth factor receptor $(\mathrm{VEGFR})^{(70)}$ inhibitors, showed growth inhibition in various CCA cell lines. Besides cell proliferation, EGFR TKIs, such as gefitinib, reduce migratory and invasive properties of CCA cells ${ }^{(45,46)}$ by interfering with EMT.

In vivo, administration of gefitinib was efficient in reducing tumor growth in $\mathrm{CCA}^{(45)}$ and $\mathrm{GB} .{ }^{(71)}$ In a mouse CCA xenograft model, EGFR inhibition by gefitinib prevented the ectopic expression of $\mathrm{E}$ cadherin in the cytoplasm and restored its membrane expression in CCA cells, ${ }^{(45)}$ implying that gefitinib could reverse EMT in CCA. Similarly, the antiErbB2 therapy, pertuzumab, reduced tumor growth in xenografted models of CCA. ${ }^{(72)}$ Furthermore, combination of treatments also proved effective in vivo. Association of erlotinib and cetuximab led to tumor growth arrest. ${ }^{(73)}$ In mice overexpressing ErbB2, GW2974, a dual EGFR/ErbB2 inhibitor, showed chemopreventive efficiency with a decrease in development of tumors along the biliary tree. ${ }^{(71)}$ Other dual anti-EGFR/ErbB2 inhibitors, such as lapatinib ${ }^{(66)}$ or NVP-AEE788, ${ }^{(74)}$ were more efficient than anti-ErbB therapies alone. Finally, combination of anti-EGFR therapies with other targeted therapies, such as as MEK, ${ }^{(68)} \mathrm{mTOR}^{(69)}$ or VEGFR ${ }^{(70)}$ inhibitors, also showed antitumor effect in vivo.

\section{Clinical Trials}

Among anti-ErbB therapies in CCA, anti-EGFR therapies have been the most studied. Several clinical trials were conducted with these drugs, alone or in combination with other therapies or chemotherapies (Supporting Table S7). Although they showed efficacy in preclinical studies, they did not show significant improvement of overall survival in phases II and III clinical trials. One recent open-label phase II trial found a higher-than-expected clinical benefit rate with the combination of gemicitabine, cisplatine, and panitimumab in KRAS wild-type CCA patients, suggesting a possible benefit of anti-EGFR therapies in selected patients. The only phase III comparing GEMOX (gemcitabine and oxaliplatine) with erlorinib 
versus chemotherapy alone did not show any difference in median overall survival. Irreversible blockers of ErbB receptors have been developed and are being tested in clinical trials. Indeed, one clinical trial showed limited, but encouraging, activity for afatinib in some patients with CCA. Only one clinical trial has assessed the efficacy of lapatinib in advanced CCA with a $0 \%$ response rate. Finally, a recent phase Ib study showed longer median overall survival in CCA patients treated with pulsatile erlotinib combined with chemotherapy compared to patients treated with standard chemotherapy, suggesting an effect for pulsatile administration of anti-EGFR. Nevertheless, results from clinical trials have been disappointing, suggesting the existence of resistance mechanisms to these therapies in CCA.

\section{RESISTANCE MECHANISMS TO ANTI-ERBB THERAPIES}

Two types of resistance (primary or innate, and secondary or acquired) are involved in anti-EGFR treatment failure in cancer.

Primary resistance often occurs as a result of primary mutations. EGFR mutations were first described in lung cancer, where they were responsible for upregulation of the downstream signaling pathways, conferring higher sensitivity to gefitinib. ${ }^{(75)}$ As mentioned before, primary mutations of EGFR TK domain have been found in CCA (Supporting Table S2), but their impact on anti-EGFR sensitivity is unknown. Resistance to anti-EGFR treatment in CCA can also result from primary mutations in downstream signaling proteins (e.g., $B R A F$ or $K R A S$ ). Mutations in $K R A S$ and $B R A F$ are found, respectively, in 3\%-54\% and in 0\%$33 \%$ of CCA. ${ }^{(76)} K R A S$ mutations are known to preclude any therapeutic benefit from anti-EGFR therapies in other cancers, but only two studies have suggested this effect in CCA for erlotinib and panitumumab. ${ }^{(77,78)}$ The recent development of a patientderived xenograft model of iCCA bearing the most frequent KRAS mutation (G12D) should provide answers on the role of this mutation in anti-EGFR treatment efficacy. ${ }^{(68)}$

Secondary resistance appears under long-term antiEGFR treatment. In lung cancer, the EGFR T790M secondary mutation leads to resistance to anti-EGFR therapies. ${ }^{(75)}$ No secondary EGFR mutation is known in CCA. However, under targeted therapy, tumor cells can use alternative signaling pathways through other growth receptors. In CCA, we recently underlined cellular and molecular mechanisms involved in secondary resistance to erlotinib. More specifically, we observed an activation of the insulin-like growth factor signaling axis that regulates an EMT program and stemness in erlotinib-resistant cells. ${ }^{(79)}$

\section{Conclusion}

ErbB receptors are involved in many physiological and pathological functions. EGFR does not seem crucial for liver development, but may play a role in cholangiocyte specification and bile duct morphogenesis. Although many studies have shown roles for ErbB receptors (especially EGFR) in hepatocytes during liver regeneration and in hepatic stellate cells during biliary fibrogenesis, their specific role in cholangiocytes remains unknown, and only mice models with specific deletion of ErbB receptors in cholangiocyte lineage would help highlight their role in development and diseases. Several signaling pathways leading to cholangiocyte proliferation are involved in different cholangiopathies, which are main risk factors for CCA. Advances in understanding the molecular basis of CCA have been made, but all mechanisms have not yet been clarified. There is an evident role of the ErbB family in CCA with EGFR and ErbB2 at the front line. Indeed, they are often overexpressed and associated with low prognostic factors. Recent data have revealed specific genetic mutations, aberrant signaling pathway activation, and microenvironment interactions, which are responsible for low prognosis and resistance to treatments in CCA. However, further research is necessary in order to decipher the role of this family in cholangiocyte pathophysiology, especially that of ErbB3 and ErbB4, which have been poorly investigated in cholangiocyte pathophysiology. Preclinical evidence of the efficiency of anti-ErbB therapies in CCA is scarce and results in clinical trials are disappointing. Data on the mechanisms involved in the chemoresistance to these molecules are lacking. Altogether, further studies are needed to enhance the molecular understanding of the role of the ErbB receptors in order to develop better therapies targeting major components of the ErbB signaling network.

Acknowledgments: A.P. is a medical intern who has received a scholarship "Year of research" from the French government. J.V. is a recipient of two following postdoctoral fellowships from the Spanish Association for the Study of the Liver (AEEH) and the Fondation ARC No. PDF2014601431. L.F. is 
supported by grants from Fondation de France (No. 2014 00047502) and La Ligue National contre le Cancer (No. RS14/75-112).

\section{REFERENCES}

1) Casalini P, Iorio MV, Galmozzi E, Menard S. Role of HER receptors family in development and differentiation. J Cell Physiol 2004;200:343-350.

2) Appert-Collin A, Hubert P, Cremel G, Bennasroune A. Role of ErbB receptors in cancer cell migration and invasion. Front Pharmacol 2015;6:283.

3) St Hilaire RJ, Hradek GT, Jones AL. Hepatic sequestration and biliary secretion of epidermal growth factor: evidence for a highcapacity uptake system. Proc Natl Acad Sci U S A 1983;80: 3797-3801.

4) Lanaya H, Natarajan A, Komposch K, Li L, Amberg N, Chen $\mathrm{L}$, et al. EGFR has a tumour-promoting role in liver macrophages during hepatocellular carcinoma formation. Nat Cell Biol 2014;16:972-981, 971-977.

5) Scheving LA, Zhang X, Stevenson MC, Threadgill DW, Russell WE. Loss of hepatocyte EGFR has no effect alone but exacerbates carbon tetrachloride-induced liver injury and impairs regeneration in hepatocyte Met-deficient mice. Am J Physiol Gastrointest Liver Physiol 2015;308:G364-G377.

6) Dunn WA, Connolly TP, Hubbard AL. Receptor-mediated endocytosis of epidermal growth factor by rat hepatocytes: receptor pathway. J Cell Biol 1986;102:24-36.

7) Ishii M, Vroman B, LaRusso NF. Morphologic demonstration of receptor-mediated endocytosis of epidermal growth factor by isolated bile duct epithelial cells. Gastroenterology 1990;98:12841291.

8) Ito $Y$, Takeda T, Sasaki Y, Sakon M, Yamada T, Ishiguro S, et al. Expression and clinical significance of the erbB family in intrahepatic cholangiocellular carcinoma. Pathol Res Pract 2001; 197:95-100.

9) Kiss A, Schnur J, Szabo Z, Nagy P. Immunohistochemical analysis of atypical ductular reaction in the human liver, with special emphasis on the presence of growth factors and their receptors. Liver 2001;21:237-246.

10) Chow NH, Huang SM, Chan SH, Mo LR, Hwang MH, Su WC. Significance of c-erbB-2 expression in normal and neoplastic epithelium of biliary tract. Anticancer Res 1995;15:10551059.

11) Si-Tayeb K, Lemaigre FP, Duncan SA. Organogenesis and development of the liver. Dev Cell 2010;18:175-189.

12) Tanimizu N, Saito H, Mostov K, Miyajima A. Long-term culture of hepatic progenitors derived from mouse Dlk+ hepatoblasts. J Cell Sci 2004;117:6425-6434.

13) Kitade M, Factor VM, Andersen JB, Tomokuni A, Kaji K, Akita $\mathrm{H}$, et al. Specific fate decisions in adult hepatic progenitor cells driven by MET and EGFR signaling. Genes Dev 2013;27: 1706-1717.

14) Ningappa M, So J, Glessner J, Ashokkumar C, Ranganathan S, Min J, et al. The role of ARF6 in biliary atresia. PLoS One 2015;10:e0138381.

15) Dianat N, Dubois-Pot-Schneider H, Steichen C, Desterke C, Leclerc P, Raveux A, et al. Generation of functional cholangiocyte-like cells from human pluripotent stem cells and HepaRG cells. Hepatology 2014;60:700-714.

16) Ogawa M, Ogawa S, Bear CE, Ahmadi S, Chin S, Li B, et al. Directed differentiation of cholangiocytes from human pluripotent stem cells. Nat Biotechnol 2015;33:853-861.
17) He J, Lu H, Zou Q, Luo L. Regeneration of liver after extreme hepatocyte loss occurs mainly via biliary transdifferentiation in zebrafish. Gastroenterology 2014;146:789-800.e8.

18) Chen $\mathrm{YH}$, Chen HL, Chien CS, Wu SH, Ho YT, Yu CH, Chang MH. Contribution of mature hepatocytes to biliary regeneration in rats with acute and chronic biliary injury. PLoS One 2015;10:e134327.

19) Limaye $\mathrm{PB}$, Bowen $\mathrm{WC}$, Orr AV, Luo J, Tseng GC, Michalopoulos GK. Mechanisms of hepatocyte growth factormediated and epidermal growth factor-mediated signaling in transdifferentiation of rat hepatocytes to biliary epithelium. HEPATOLOGY 2008;47:1702-1713.

20) Lazaridis KN, LaRusso NF. The Cholangiopathies. Mayo Clin Proc 2015;90:791-800.

21) Matsumoto K, Fujii H, Michalopoulos G, Fung JJ, Demetris AJ. Human biliary epithelial cells secrete and respond to cytokines and hepatocyte growth factors in vitro: interleukin-6, hepatocyte growth factor and epidermal growth factor promote DNA synthesis in vitro. Hepatology 1994;20:376-382.

22) Sato $Y$, Harada K, Kizawa K, Sanzen T, Furubo S, Yasoshima $\mathrm{M}$, et al. Activation of the MEK5/ERK5 cascade is responsible for biliary dysgenesis in a rat model of Caroli's disease. Am J Pathol 2005;166:49-60.

23) Sirica AE, Gainey TW. A new rat bile ductular epithelial cell culture model characterized by the appearance of polarized bile ducts in vitro. Hepatology 1997;26:537-549.

24) Guntaka SR, Samak G, Seth A, LaRusso NF, Rao R. Epidermal growth factor protects the apical junctional complexes from hydrogen peroxide in bile duct epithelium. Lab Invest 2011;91: 1396-1409.

25) Firrincieli D, Zuniga S, Rey C, Wendum D, Lasnier E, Rainteau D, et al. Vitamin D nuclear receptor deficiency promotes cholestatic liver injury by disruption of biliary epithelial cell junctions in mice. Hepatology 2013;58:1401-1412.

26) Finzi L, Barbu V, Burgel PR, Mergey M, Kirkwood KS, Wick $\mathrm{EC}$, et al. MUC5AC, a gel-forming mucin accumulating in gallstone disease, is overproduced via an epidermal growth factor receptor pathway in the human gallbladder. Am J Pathol 2006; 169:2031-2041.

27) Kim HJ, Kim JS, Kang CD, Lee SJ, Kim JY, Yeon JE, et al. [Expression of epidermal growth factor receptor, ErbB2 and matrix metalloproteinase-9 in hepatolithiasis and cholangiocarcinoma]. [Article in Korean]. Korean J Gastroenterol 2005;45:52-59.

28) Zhou Q, Gong Y, Huang F, Lin Q, Zeng B, Li Z, Chen R. Expression levels and significance of nuclear factor-kappaB and epidermal growth factor receptor in hepatolithiasis associated with intrahepatic cholangiocarcinoma. Dig Surg 2013;30:309316.

29) Liu Z, Tian F, Feng $X$, He $Y$, Jiang $P$, Li J, et al. LPS increases MUC5AC by TACE/TGF-alpha/EGFR pathway in human intrahepatic biliary epithelial cell. Biomed Res Int 2013;2013: 165715.

30) Garcia-Irigoyen $\mathbf{O}$, Carotti S, Latasa MU, Uriarte I, Fernandez-Barrena MG, Elizalde $\mathrm{M}$, et al. Matrix metalloproteinase-10 expression is induced during hepatic injury and plays a fundamental role in liver tissue repair. Liver Int 2014;34:e257-e270.

31) Sung R, Lee SH, Ji M, Han JH, Kang MH, Kim JH, et al. Epithelial-mesenchymal transition-related protein expression in biliary epithelial cells associated with hepatolithiasis. J Gastroenterol Hepatol 2014;29:395-402. 
32) Fabris L, Brivio S, Cadamuro M, Strazzabosco M. Revisiting epithelial-to-mesenchymal transition in liver fibrosis: clues for a better understanding of the "reactive" biliary epithelial phenotype. Stem Cells Int 2016;2016:2953727.

33) Trussoni CE, Tabibian JH, Splinter PL, O’Hara SP. Lipopolysaccharide (LPS)-induced biliary epithelial cell NRas activation requires epidermal growth factor receptor (EGFR). PLoS One 2015;10:e0125793.

34) Svinka J, Pflugler S, Mair M, Marschall HU, Hengstler JG, Stiedl $\mathrm{P}$, et al. Epidermal growth factor signaling protects from cholestatic liver injury and fibrosis. J Mol Med (Berl) 2017;95: 109-117.

35) Endo K, Yoon BI, Pairojkul C, Demetris AJ, Sirica AE. ERBB2 overexpression and cyclooxygenase-2 up-regulation in human cholangiocarcinoma and risk conditions. HePATOLOGY 2002;36: 439-450.

36) Waanders E, Van Krieken JH, Lameris AL, Drenth JP. Disrupted cell adhesion but not proliferation mediates cyst formation in polycystic liver disease. Mod Pathol 2008;21:1293-1302.

37) Nauta J, Sweeney WE, Rutledge JC, Avner ED. Biliary epithelial cells from mice with congenital polycystic kidney disease are hyperresponsive to epidermal growth factor. Pediatr Res 1995;37: 755-763.

38) Sweeney WE, Chen Y, Nakanishi K, Frost P, Avner ED. Treatment of polycystic kidney disease with a novel tyrosine kinase inhibitor. Kidney Int 2000;57:33-40.

39) Torres VE, Sweeney WE, Jr., Wang X, Qian Q, Harris PC, Frost $\mathrm{P}$, Avner ED. Epidermal growth factor receptor tyrosine kinase inhibition is not protective in PCK rats. Kidney Int 2004; 66:1766-1773.

40) Banales JM, Cardinale V, Carpino G, Marzioni M, Andersen JB, Invernizzi P, et al. Expert consensus document: cholangiocarcinoma: current knowledge and future perspectives consensus statement from the European Network for the Study of Cholangiocarcinoma (ENS-CCA). Nat Rev Gastroenterol Hepatol 2016;13:261-280.

41) Sia D, Hoshida Y, Villanueva A, Roayaie S, Ferrer J, Tabak B, et al. Integrative molecular analysis of intrahepatic cholangiocarcinoma reveals 2 classes that have different outcomes. Gastroenterology 2013;144:829-840.

42) Jang S, Chun SM, Hong SM, Sung CO, Park H, Kang HJ, et al. High throughput molecular profiling reveals differential mutation patterns in intrahepatic cholangiocarcinomas arising in chronic advanced liver diseases. Mod Pathol 2014;27:731-739.

43) Meng L, Tian Z, Wang Y, Liu Y, Liu J. Predictive and prognostic molecular markers for cholangiocarcinoma in Han Chinese population. Int J Clin Exp Med 2015;8:13680-13689.

44) Yoon JH, Gwak GY, Lee HS, Bronk SF, Werneburg NW, Gores GJ. Enhanced epidermal growth factor receptor activation in human cholangiocarcinoma cells. J Hepatol 2004;41:808-814.

45) Claperon A, Mergey M, Nguyen Ho-Bouldoires TH, Vignjevic D, Wendum D, Chretien Y, et al. EGF/EGFR axis contributes to the progression of cholangiocarcinoma through the induction of an epithelial-mesenchymal transition. J Hepatol 2014;61:325332.

46) Claperon A, Guedj N, Mergey M, Vignjevic D, DesboisMouthon C, Boissan M, et al. Loss of EBP50 stimulates EGFR activity to induce EMT phenotypic features in biliary cancer cells. Oncogene 2012;31:1376-1388.

47) Yoon JH, Werneburg NW, Higuchi H, Canbay AE, Kaufmann $\mathrm{SH}, \mathrm{Akgul} \mathrm{C}$, et al. Bile acids inhibit Mcl-1 protein turnover via an epidermal growth factor receptor/Raf-1-dependent mechanism. Cancer Res 2002;62:6500-6505.
48) Werneburg NW, Yoon JH, Higuchi H, Gores GJ. Bile acids activate EGF receptor via a TGF-alpha-dependent mechanism in human cholangiocyte cell lines. Am J Physiol Gastrointest Liver Physiol 2003;285:G31-G36.

49) Liu R, Li X, Qiang X, Luo L, Hylemon PB, Jiang Z, et al. Taurocholate induces cyclooxygenase- 2 expression via the sphingosine 1-phosphate receptor 2 in a human cholangiocarcinoma cell line. J Biol Chem 2015;290:30988-31002.

50) Reich M, Deutschmann K, Sommerfeld A, Klindt C, Kluge S, Kubitz R, et al. TGR5 is essential for bile acid-dependent cholangiocyte proliferation in vivo and in vitro. Gut 2016;65:487501.

51) $\mathrm{Wu} \mathrm{T}$. Cyclooxygenase- 2 and prostaglandin signaling in cholangiocarcinoma. Biochim Biophys Acta 2005;1755:135-150.

52) Han $\mathrm{C}, \mathrm{Wu}$ T. Cyclooxygenase-2-derived prostaglandin E2 promotes human cholangiocarcinoma cell growth and invasion through EP1 receptor-mediated activation of the epidermal growth factor receptor and Akt. J Biol Chem 2015;290:17806.

53) Finzi L, Shao MX, Paye F, Housset C, Nadel JA. Lipopolysaccharide initiates a positive feedback of epidermal growth factor receptor signaling by prostaglandin E2 in human biliary carcinoma cells. J Immunol 2009;182:2269-2276.

54) Wehbe H, Henson R, Meng F, Mize-Berge J, Patel T. Interleukin-6 contributes to growth in cholangiocarcinoma cells by aberrant promoter methylation and gene expression. Cancer Res 2006;66:10517-10524.

55) Nguyen Ho-Bouldoires TH, Claperon A, Mergey M, Wendum D, Desbois-Mouthon C, Tahraoui S, et al. Mitogen-activated protein kinase-activated protein kinase 2 mediates resistance to hydrogen peroxide-induced oxidative stress in human hepatobiliary cancer cells. Free Radic Biol Med 2015;89:34-46.

56) Kiguchi K, Carbajal S, Chan K, Beltran L, Ruffino L, Shen J, et al. Constitutive expression of ErbB-2 in gallbladder epithelium results in development of adenocarcinoma. Cancer Res 2001;61: 6971-6976.

57) Lai GH, Zhang Z, Shen XN, Ward DJ, Dewitt JL, Holt SE, et al. erbB-2/neu transformed rat cholangiocytes recapitulate key cellular and molecular features of human bile duct cancer. Gastroenterology 2005;129:2047-2057.

58) Lai GH, Zhang Z, Sirica AE. Celecoxib acts in a cyclooxygenase-2-independent manner and in synergy with emodin to suppress rat cholangiocarcinoma growth in vitro through a mechanism involving enhanced Akt inactivation and increased activation of caspases-9 and -3. Mol Cancer Ther 2003;2:265271.

59) Kitamura T, Srivastava J, DiGiovanni J, Kiguchi K. Bile acid accelerates erbB2-induced pro-tumorigenic activities in biliary tract cancer. Mol Carcinog 2015;54:459-472.

60) Claperon A, Mergey M, Aoudjehane L, Ho-Bouldoires TH, Wendum D, Prignon A, et al. Hepatic myofibroblasts promote the progression of human cholangiocarcinoma through activation of epidermal growth factor receptor. HEPATOLOGY 2013;58:20012011.

61) Torres VE, Sweeney WE, Jr., Wang X, Qian Q, Harris PC, Frost P, Avner ED. EGF receptor tyrosine kinase inhibition attenuates the development of PKD in Han:SPRD rats. Kidney Int 2003;64:1573-1579.

62) Li F, Zhou Y, Cheng N, Mao H, Jiang L, Li N, et al. Epidermal growth factor receptor as a target for anti-proliferative treatment of proliferative cholangitis in hepatolithiasis. J Surg Res 2011;166:87-94

63) Fuchs BC, Hoshida Y, Fujii T, Wei L, Yamada S, Lauwers GY, et al. Epidermal growth factor receptor inhibition attenuates liver 
fibrosis and development of hepatocellular carcinoma. HEPATOLOGY 2014;59:1577-1590.

64) Yabuuchi S, Katayose Y, Oda A, Mizuma M, Shirasou S, Sasaki T, et al. ZD1839 (IRESSA) stabilizes p27Kip1 and enhances radiosensitivity in cholangiocarcinoma cell lines. Anticancer Res 2009;29:1169-1180.

65) Ariyama H, Qin B, Baba E, Tanaka R, Mitsugi K, Harada M, Nakano S. Gefitinib, a selective EGFR tyrosine kinase inhibitor, induces apoptosis through activation of Bax in human gallbladder adenocarcinoma cells. J Cell Biochem 2006;97:724-734.

66) Zhang Z, Oyesanya RA, Campbell DJ, Almenara JA, Dewitt JL, Sirica AE. Preclinical assessment of simultaneous targeting of epidermal growth factor receptor (ErbB1) and ErbB2 as a strategy for cholangiocarcinoma therapy. Hepatology 2010;52:975986.

67) Pignochino Y, Sarotto I, Peraldo-Neia C, Penachioni JY, Cavalloni G, Migliardi G, et al. Targeting EGFR/HER2 pathways enhances the antiproliferative effect of gemcitabine in biliary tract and gallbladder carcinomas. BMC Cancer 2010;10: 631.

68) Cavalloni G, Peraldo-Neia C, Varamo C, Chiorino G, Sassi F, Aglietta M, Leone F. Preclinical activity of EGFR and MEK1/2 inhibitors in the treatment of biliary tract carcinoma. Oncotarget 2016;7:52354-52363.

69) Herberger B, Berger W, Puhalla H, Schmid K, Novak S, Brandstetter A, et al. Simultaneous blockade of the epidermal growth factor receptor/mammalian target of rapamycin pathway by epidermal growth factor receptor inhibitors and rapamycin results in reduced cell growth and survival in biliary tract cancer cells. Mol Cancer Ther 2009;8:1547-1556.

70) Yoshikawa D, Ojima H, Kokubu A, Ochiya T, Kasai S, Hirohashi S, Shibata T. Vandetanib (ZD6474), an inhibitor of VEGFR and EGFR signalling, as a novel molecular-targeted therapy against cholangiocarcinoma. Br J Cancer 2009;100:12571266.

71) Kiguchi K, Ruffino L, Kawamoto T, Ajiki T, Digiovanni J. Chemopreventive and therapeutic efficacy of orally active tyrosine kinase inhibitors in a transgenic mouse model of gallbladder carcinoma. Clin Cancer Res 2005;11:5572-5580.

72) Kawamoto T, Ishige K, Thomas M, Yamashita-Kashima $Y$, Shu $\mathrm{S}$, Ishikura $\mathrm{N}$, et al. Overexpression and gene amplification of EGFR, HER2, and HER3 in biliary tract carcinomas, and the possibility for therapy with the HER2-targeting antibody pertuzumab. J Gastroenterol 2015;50:467-479.

73) Jimeno A, Rubio-Viqueira B, Amador ML, Oppenheimer D, Bouraoud N, Kulesza P, et al. Epidermal growth factor receptor dynamics influences response to epidermal growth factor receptor targeted agents. Cancer Res 2005;65:3003-3010.

74) Wiedmann M, Feisthammel J, Bluthner T, Tannapfel A, Kamenz T, Kluge A, et al. Novel targeted approaches to treating biliary tract cancer: the dual epidermal growth factor receptor and ErbB-2 tyrosine kinase inhibitor NVP-AEE788 is more efficient than the epidermal growth factor receptor inhibitors gefitinib and erlotinib. Anticancer Drugs 2006;17:783-795.

75) Kobayashi S, Boggon TJ, Dayaram T, Janne PA, Kocher O, Meyerson M, et al. EGFR mutation and resistance of nonsmall-cell lung cancer to gefitinib. N Engl J Med 2005;352:786792.

76) Hezel AF, Deshpande V, Zhu AX. Genetics of biliary tract cancers and emerging targeted therapies. J Clin Oncol 2010;28: 3531-3540.

77) Ferraro D, Goldstein D, O'Connell RL, Zalcberg JR, Sjoquist KM, Tebbutt NC, et al. TACTIC: a multicentre, open-label, single-arm phase II trial of panitumumab, cisplatin, and gemcitabine in biliary tract cancer. Cancer Chemother Pharmacol 2016; 78:361-367.

78) Kim ST, Jang KT, Lee J, Jang HM, Choi HJ, Jang HL, et al. Molecular subgroup analysis of clinical outcomes in a phase 3 study of gemcitabine and oxaliplatin with or without erlotinib in advanced biliary tract cancer. Transl Oncol 2015;8:40-46.

79) Vaquero J, Clapéron A, Mergey M, Desbois-Mouthon C, Praz F, Fouassier L. Long-term inhibition of EGFR in human cholangiocarcinoma cells leads to the induction of an epithelial to mesenchymal transition program and activation of Insulin/Insulin Growth Factor 1 Receptors. J Hepatol 2015;62:S797.

Author names in bold designate shared co-first authorship. 
Role of ErbB/HER family of receptor tyrosine kinases in cholangiocyte biology

Anna Pellat ${ }^{1}$, Javier Vaquero ${ }^{1,2}$ and Laura Fouassier ${ }^{1}$

1- Sorbonne Universités, UPMC Université Paris 06, INSERM, Centre de Recherche Saint-

Antoine (CRSA), F-75012 Paris, France

2-FONDATION ARC, F-94803 Villejuif, France

\section{Key words}

EGFR, Bile ducts, Cholangiopathy, Cholangiocarcinoma, Therapy

\section{Contact information}

Laura Fouassier, Ph.D.

INSERM UMR_S 893, Centre de Recherche Saint-Antoine (CRSA)

184 rue du Faubourg Saint-Antoine

75012 Paris, France

33698774001 (phone)

laura.fouassier@inserm.fr

\section{Financial support}

Fondation ARC NPDF2014601431.

\section{Competing interests}

The authors declare no competing interests. 
Supplementary Table 1

\begin{tabular}{|c|c|c|c|c|c|c|c|}
\hline $\begin{array}{l}\text { Type of } \\
\text { CCA }\end{array}$ & $\begin{array}{c}\text { Number } \\
\text { of } \\
\text { samples }\end{array}$ & $\begin{array}{l}\% \text { of cases with } \\
\text { expression }\end{array}$ & Expression levels & $\begin{array}{c}\text { Gene } \\
\text { Amplification }\end{array}$ & $\begin{array}{c}\text { Correlation } \\
\text { with clinical } \\
\text { factors }\end{array}$ & $\begin{array}{l}\text { Survival } \\
\text { analysis }\end{array}$ & Ref. \\
\hline iCCA & 37 & $32 \%$ & Expression & N.D. & N.S. & N.D. & (1) \\
\hline $\begin{array}{l}\text { eCCA } \\
\text { GB } \\
\text { AV }\end{array}$ & 29 & $100 \%$ & $\begin{array}{l}\text { Moderate to Strong } \\
\text { expression (defined } \\
\text { as } 2+\text { or } 3+\text { ) }\end{array}$ & N.D. & N.D. & N.D. & (2) \\
\hline iCCA & 38 & $45 \%$ & Expression & N.D. & S. & N.D. & (3) \\
\hline iCCA & 48 & $81 \%$ & $\begin{array}{l}\text { Moderate to Strong } \\
\text { expression (defined } \\
\text { as } 1+\text { or } 2+\text { ) }\end{array}$ & N.D. & N.S. & $\begin{array}{c}\text { N.S. } \\
\text { (univariate } \\
\text { analysis) }\end{array}$ & (4) \\
\hline CCA & 30 & $47 \%$ & $\begin{array}{l}\text { Strong expression } \\
\text { (defined as } 3+\text { ) }\end{array}$ & N.D. & N.D. & N.D. & (5) \\
\hline iCCA & 122 & $10 \%$ & Expression & N.D. & N.D. & N.D. & (6) \\
\hline CCA & 221 & $8 \%$ & $\begin{array}{l}\text { Overexpression } \\
\text { (defined as } 2+\text { and } \\
3+\text { ) }\end{array}$ & $6 \%$ & N.S. & N.D. & (7) \\
\hline iCCA & 28 & $11 \%$ & & N.D. & N.S. & N.D. & \\
\hline eCCA & 78 & $5 \%$ & & N.D. & N.S. & N.D. & \\
\hline GB & 89 & $12 \%$ & & N.D. & N.S. & N.D. & \\
\hline AV & 26 & $0 \%$ & & N.D. & N.S. & N.D. & \\
\hline $\begin{array}{c}\mathrm{CCA} / \mathrm{G} \\
\mathrm{B}\end{array}$ & 72 & $43 \%$ & $\begin{array}{l}\text { Overexpression } \\
\text { (defined as } 2+\text { or } 3+\text { ) }\end{array}$ & N.D. & $\mathrm{S}$. & N.S. & (8) \\
\hline $\mathrm{CCA}$ & 24 & $63 \%$ & Expression & N.D. & N.D. & $\begin{array}{l}\text { N.S. } \\
\text { (univariate } \\
\text { analysis) }\end{array}$ & (9) \\
\hline CCA & 114 & $12 \%$ & $\begin{array}{c}\text { Overexpression } \\
\text { (defined as } 2+\text { and } \\
3+\text { ) }\end{array}$ & N.D. & N.D. & N.D. & (10) \\
\hline GB & 77 & $16 \%$ & & N.D. & N.D. & N.D. & \\
\hline $\begin{array}{l}\text { iCCA } \\
\text { eCCA }\end{array}$ & $\begin{array}{l}21 \\
16\end{array}$ & $\begin{array}{l}0 \% \\
0 \%\end{array}$ & & $\begin{array}{l}\text { N.D. } \\
\text { N.D. }\end{array}$ & N.D. & N.D. & \\
\hline CCA & 236 & $23 \%$ & $\begin{array}{c}\text { Overexpression } \\
\text { (defined as } 2+\text { and } \\
3+\text { ) }\end{array}$ & N.D. & S. & $\begin{array}{l}\text { Poor } \\
\text { (multivariate } \\
\text { analysis) }\end{array}$ & (11) \\
\hline iCCA & 106 & $27 \%$ & & N.D. & N.S. & Poor & \\
\hline eCCA & 130 & $25 \%$ & & N.D. & S. & Poor & \\
\hline GB & 16 & $94 \%$ & $\begin{array}{c}\text { Overexpression } \\
\text { (defined as } 1+\text { and } \\
\text { over) }\end{array}$ & N.D. & S. & Poor & (12) \\
\hline CCA & 89 & $64 \%$ & $\begin{array}{c}\text { Expression } \\
\text { (membranous } \\
\text { immunostaining) }\end{array}$ & N.D. & S. & Poor & (13) \\
\hline CCA & 56 & $61 \%$ & Expression & N.D. & N.S. & $\begin{array}{l}\text { N.S } \\
\text { (univariate } \\
\text { analysis) }\end{array}$ & (14) \\
\hline $\begin{array}{l}\text { iCCA } \\
\text { eCCA } \\
\text { GB }\end{array}$ & 51 & $80 \%$ & Expression & $0.02 \%$ & N.D. & N.D. & (15) \\
\hline CCA & 49 & $65 \%$ & Expression & N.D. & S. & N.D. & (16) \\
\hline $\mathrm{GB}$ & 13 & $39 \%$ & Expression & N.D. & & N.D. & \\
\hline iCCA & 17 & $100 \%$ & Expression & N.D. & & N.D. & \\
\hline eCCA & 19 & $53 \%$ & Expression & N.D. & & N.D. & \\
\hline iCCA & 33 & $58 \%$ & Expression & N.D. & S. & $\begin{array}{c}\text { Poor } \\
\text { (univariate } \\
\text { and } \\
\text { multivariate } \\
\text { analysis) }\end{array}$ & (17) \\
\hline CCA & 152 & $24 \%$ & Overexpression & N.D. & S. & Poor & (18) \\
\hline
\end{tabular}




$\begin{array}{lllc}\text { iCCA } & 58 & 35 \% & \text { (defined as } 2+\text { or } 3+\text { ) } \\ \text { eCCA } & 94 & 22 \% & \\ \text { iCCA } & 58 & 22 \% & \text { Overexpression } \\ & & & \text { (defined as } 2+\text { or } 3+\text { ) }\end{array}$

eCCA 94

$35 \%$

$70 \%$
$58 \%$
$81 \%$
$25 \%$
$31 \%$

eCCA $\quad 110$

$21 \%$

$18 \%$

CCA

113

\begin{tabular}{cl} 
GB & 47 \\
CCA & 66 \\
\hline
\end{tabular}

iCCA 25

eCCA 84

iCCA $\quad 106$

iCCA

36

Overexpression

(defined as $2+$ or $3+$ )
$19 \%$

$17 \%$

$38 \%$
N.D.

N.D.

(defined as $2+$ or $3+$ )

Overexpression

(defined as $1+$ to $3+$ )

Overexpression

(defined as $2+$ or $3+$ )

N.D.

N.D.

N.D.

N.D.

Overexpression

(defined as 2+ and

over)

$\begin{array}{lr} & 4 \% \\ & 12 \% \\ \text { Expression } & \text { N.D } \\ \text { Expression } & \text { N.D. }\end{array}$

Expression

N.D.

$4 \%$

$2 \%$

D.

Abbreviations: AV, Ampulla $81 \%$ Expression N.D.

N.D.

$\begin{array}{ll}\text { Expression } & \text { N.D. } \\ \text { Expression } & \text { N.D. }\end{array}$

gallbladder; N.D., not determined; N.S., not significant; S., significant. 
Supplementary Table 2 Mutations of ErbB members in CCA

\begin{tabular}{|c|c|c|c|}
\hline Type of CCA & $\begin{array}{l}\text { Number of cases with } \\
\text { EGFR mutations (\%) }\end{array}$ & Mutated exon & Ref. \\
\hline $22 \mathrm{CCA}$ & $3(13.6 \%)$ & 19 & (26) \\
\hline 22 CCA & $0(0 \%)$ & & (27) \\
\hline $40 \mathrm{CCA}$ & $6(15 \%)$ & $19,20,21$ & (28) \\
\hline $11 \mathrm{~GB}$ & 1 & & \\
\hline 15 iCCA & 3 & & \\
\hline 14 eCCA & 2 & & \\
\hline 142 iCCA & $2(1.4 \%)$ & 21 & (29) \\
\hline $\begin{array}{l}153 \text { CCA } \\
70 \text { iCCA }\end{array}$ & $2(1,3 \%)$ & 20 & (19) \\
\hline 57 eCCA & $1(1,7 \%)$ & & \\
\hline $26 \mathrm{~GB}$ & $1(3,8 \%)$ & & \\
\hline $51 \mathrm{CCA}(\mathrm{GB})$ & $2(3.9 \%)$ & 5,21 & (30) \\
\hline 81 iCCA & $6(7,4 \%)$ & 19 & (31) \\
\hline 38 iCC with CALD & $5(13 \%)$ & & \\
\hline 433 iCC with normal liver & $1(2 \%)$ & & \\
\hline 137 CCA & $13(9.5 \%)$ & 20,21 & (32) \\
\hline 57 eCCA & 9 & & \\
\hline 45 iCCA & 2 & & \\
\hline $35 \mathrm{~GB}$ & 2 & & \\
\hline 116 CCA & $2(1.7 \%)$ & 20 & (33) \\
\hline $34 \mathrm{~GB}$ & 0 & & \\
\hline 87 others & 2 & & \\
\hline Type of CCA & $\begin{array}{l}\text { Number of cases with } \\
\text { ErbB2 mutations (\%) }\end{array}$ & Mutated exon & Ref. \\
\hline $22 \mathrm{CCA}$ & $0(0 \%)$ & & (27) \\
\hline 153 CCA & & & (19) \\
\hline 70 iCCA & $0(0 \%)$ & & \\
\hline 57 eCCA & $1(0,7 \%)$ & N.D. & \\
\hline $26 \mathrm{~GB}$ & $1(3,8 \%)$ & N.D. & \\
\hline $51 \mathrm{CCA}(\mathrm{GB})$ & $5(9,8 \%)$ & $7,8,17,21$ & (30) \\
\hline Type of CCA & $\begin{array}{l}\text { Number of cases with } \\
\text { ErbB3 mutations (\%) }\end{array}$ & Mutated exon & Ref. \\
\hline $51 \mathrm{CCA}(\mathrm{GB})$ & $6(11,8 \%)$ & $3,12,25$ & (30) \\
\hline Type of CCA & $\begin{array}{l}\text { Number of cases with } \\
\text { ErbB4 mutations (\%) }\end{array}$ & Mutated exon & Ref. \\
\hline $153 \mathrm{CCA}$ & $1(0,7 \%)$ & N.D. & (19) \\
\hline 70 iCCA & $1(1,4 \%)$ & N.D. & \\
\hline 57 eCCA & $0(0 \%)$ & & \\
\hline $26 \mathrm{~GB}$ & $0(0 \%)$ & & \\
\hline $51 \mathrm{CCA}(\mathrm{GB})$ & $2(3.9 \%)$ & 3 & $(30)$ \\
\hline \multicolumn{4}{|c|}{$\begin{array}{l}\text { Abbreviations: CALD, chronic advanced liver disease; CCA, cholangiocarcinoma; } \\
\text { iCCA, intrahepatic CCA; eCCA, extrahepatic CCA; GB, gallbladder; N.d, not } \\
\text { determined. }\end{array}$} \\
\hline
\end{tabular}




\begin{tabular}{|c|c|c|c|c|c|c|c|}
\hline \multicolumn{8}{|c|}{ Supplementary Table 3} \\
\hline Type of CCA & $\begin{array}{c}\text { Number } \\
\text { of } \\
\text { samples }\end{array}$ & $\begin{array}{l}\text { \% of cases } \\
\text { with } \\
\text { expression }\end{array}$ & $\begin{array}{l}\text { Expression } \\
\text { levels }\end{array}$ & $\begin{array}{l}\text { Correlation } \\
\text { with } \\
\text { clinical } \\
\text { factors }\end{array}$ & $\begin{array}{l}\text { Survival } \\
\text { analysis }\end{array}$ & $\begin{array}{c}\text { Gene } \\
\text { amplification }\end{array}$ & Ref. \\
\hline CCA & 63 & $73 \%$ & Expression & N.D. & N.D. & N.D. & (34) \\
\hline CCA & 10 & $0 \%$ & Overexpression & N.D. & N.D. & N.D. & (35) \\
\hline CCA & 6 & $67 \%$ & Overexpression & N.D. & N.D. & N.D. & (36) \\
\hline CCA & 47 & $64 \%$ & Overexpression & S. & N.D. & N.D. & (37) \\
\hline iCCA & 18 & & Overexpression & N.D. & N.D. & N.D. & \\
\hline $\mathrm{GB}$ & 11 & & Overexpression & N.D. & N.D. & N.D. & \\
\hline AV & 18 & & Overexpression & N.D. & N.D. & N.D. & \\
\hline CCA & 47 & $70 \%$ & Overexpression & N.D. & N.D. & N.D. & (38) \\
\hline iCCA & 42 & $29 \%$ & Expression & N.D. & N.D. & N.D. & (39) \\
\hline iCCA & $\begin{array}{c}19 \\
\text { (Thai } \\
\text { patients) }\end{array}$ & $26 \%$ & Expression & N.D. & N.D. & N.D. & \\
\hline iCCA & 23 & $30 \%$ & Expression & N.D. & N.D. & N.D. & \\
\hline & $\begin{array}{l}\text { (Japanese } \\
\text { patients) }\end{array}$ & & & & & & \\
\hline iCCA & 38 & $53 \%$ & Expression & N.S. & N.D. & N.D. & (3) \\
\hline iCCA & 81 & $56 \%$ & Expression & S. & $\begin{array}{c}\text { N.S. } \\
\text { (univariate } \\
\text { and } \\
\text { multivariate } \\
\text { analysis) }\end{array}$ & $4 \%$ & (40) \\
\hline iCCA & 22 & $82 \%$ & Overexpression & N.S. & N.D. & $100 \%$ & (41) \\
\hline CCA & 71 & $30 \%$ & Overexpression & S. & N.D. & N.D. & (42) \\
\hline iCCA & 48 & $4 \%$ & Overexpression & N.S. & N.S. & $4 \%$ & $(4)$ \\
\hline CCA & 221 & $10 \%$ & Overexpression & S. & N.D. & $6,8 \%$ & (7) \\
\hline iCCA & 28 & $0 \%$ & Overexpression & N.D. & N.D. & & \\
\hline eCCA & 78 & $5 \%$ & Overexpression & N.D. & N.D. & & \\
\hline GB & 89 & $16 \%$ & Overexpression & N.D. & N.D. & & \\
\hline $\mathrm{AV}$ & 26 & $12 \%$ & Overexpression & N.D. & N.D. & & \\
\hline iCCA & 31 & $32 \%$ & $\begin{array}{c}\text { Strong } \\
\text { expression }\end{array}$ & S. & N.D. & N.D. & $(43)$ \\
\hline $\begin{array}{c}\text { CCA } \\
(44 \mathrm{CCA} \\
+28 \mathrm{~GB})\end{array}$ & 72 & $65 \%$ & Overexpression & N.S & $\begin{array}{l}\text { N.S. } \\
\text { (univariate } \\
\text { and } \\
\text { multivariate } \\
\text { analysis) }\end{array}$ & N.D. & (8) \\
\hline & 114 & $21 \%$ & Overexpression & N.D. & N.D. & & (10) \\
\hline GB & 77 & $31 \%$ & Overexpression & N.D. & N.D. & $21 \%$ & \\
\hline iCCA & 21 & $33 \%$ & Overexpression & N.D. & N.D. & $0 \%$ & \\
\hline eCCA & 16 & $31 \%$ & Overexpression & N.D. & N.D. & $21 \%$ & \\
\hline CCA & 236 & $5 \%$ & Overexpression & S. & N.D. & N.D. & (11) \\
\hline iCCA & 106 & $1 \%$ & Overexpression & N.D. & N.D. & N.D. & \\
\hline eCCA & 130 & $9 \%$ & Overexpression & S. & N.D. & N.D. & \\
\hline GB & 16 & $6 \%$ & Overexpression & N.D. & N.D. & N.D. & (12) \\
\hline CCA & 124 & $20 \%$ & Overexpression & N.D. & N.D. & $5 \%$ & (14) \\
\hline CCA & 51 & $4 \%$ & Overexpression & N.D. & N.D. & N.D. & (15) \\
\hline CCA & 39 & $18 \%$ & Expression & N.D. & N.D. & $\begin{array}{l}8 \% \text { (tested only } \\
\text { for scores } 2+ \\
\text { and } 3+\text { ) }\end{array}$ & (16) \\
\hline GB & 13 & $10 \%$ & Expression & N.D. & N.D. & & \\
\hline iCCA & 17 & $10 \%$ & Expression & N.D. & N.D. & & \\
\hline eCCA & 19 & $26 \%$ & Expression & N.D. & N.D. & & \\
\hline eCCA & 224 & $6 \%$ & Overexpression & S. & N.S. & N.D. & (44) \\
\hline
\end{tabular}




\begin{tabular}{cccccccc}
\hline & \multicolumn{3}{c}{ (defined as 3+) } & $\begin{array}{c}\text { (univariate } \\
\text { analysis) }\end{array}$ \\
\hline eCCA & 94 & $4 \%$ & Overexpression & N.D. & N.D. & $3,5 \%$ & $(18)$ \\
CCA & 175 & $3 \%$ & & N.D. & N.D. & N.D. & $(20)$ \\
iCCA & 65 & $0 \%$ & Overexpression & N.S. & N.D. & N.D. \\
eCCA & 110 & $5 \%$ & Overexpression & S. & N.D. & N.D. & $(21)$ \\
CCA & 113 & $27 \%$ & & N.D. & N.D. & $17 \%$ & \\
GB & 47 & $32 \%$ & Overexpression & N.D. & N.D. & $23 \%$ \\
CCA & 66 & $23 \%$ & Overexpression & N.D. & N.D. & \\
\hline Abbreviations: AV, Ampulla of Vater; CCA, cholangiocarcinoma; iCCA, intrahepatic CCA; eCCA, extrahepatic CCA; \\
GB, gallbladder; N.D., not determined; N.S., not significant; S., significant.
\end{tabular}


Supplementary Table 4 Reported frequencies of human CCA exhibiting varying degrees of HER3 activity

\begin{tabular}{|c|c|c|c|c|c|c|c|}
\hline Type of CCA & $\begin{array}{c}\text { Number } \\
\text { of } \\
\text { samples }\end{array}$ & $\begin{array}{l}\% \text { of cases } \\
\text { with } \\
\text { expression }\end{array}$ & Expression levels & $\begin{array}{c}\text { Correlation } \\
\text { with clinical } \\
\text { factors }\end{array}$ & $\begin{array}{l}\text { Survival } \\
\text { analysis }\end{array}$ & $\begin{array}{c}\text { Gene } \\
\text { amplification }\end{array}$ & Ref. \\
\hline eCCA & 230 & $39 \%$ & Overexpression & S. & S. & N.D. & $(44)$ \\
\hline CCA & 175 & & & & & & \\
\hline iCCA & 65 & $12.3 \%$ & Overexpression & S. & N.D. & N.D. & (20) \\
\hline eCCA & 110 & $11.8 \%$ & Overexpression & N.S. & N.D. & N.D. & \\
\hline CCA & 113 & & & & & & \\
\hline GB & 47 & $34 \%$ & Overexpression & N.D. & N.D. & $26 \%$ & (21) \\
\hline CCA & 66 & $29 \%$ & Overexpression & N.D. & N.D. & $27 \%$ & \\
\hline
\end{tabular}

\begin{tabular}{|c|c|c|c|c|c|c|c|}
\hline \multicolumn{2}{|c|}{ Supplementary Table 5} & \multicolumn{6}{|c|}{ Reported frequencies of human CCA exhibiting varying degrees of HER4 activity } \\
\hline Type of CCA & $\begin{array}{l}\text { Number } \\
\text { of } \\
\text { samples }\end{array}$ & $\begin{array}{l}\% \text { of cases } \\
\text { with } \\
\text { expression }\end{array}$ & $\begin{array}{l}\text { Level of } \\
\text { expression }\end{array}$ & $\begin{array}{l}\text { Clinical } \\
\text { factors }\end{array}$ & $\begin{array}{l}\text { Survival } \\
\text { analysis }\end{array}$ & $\begin{array}{c}\text { Gene } \\
\text { amplification }\end{array}$ & Ref \\
\hline iCCA & 38 & $39.5 \%$ & Expression & S. & N.D. & N.D. & (3) \\
\hline CCA & 175 & & & & & & \\
\hline iCCA & 65 & $63.1 \%$ & Overexpression & N.S. & N.S. & N.D. & $(20)$ \\
\hline eCCA & 110 & $56.4 \%$ & Overexpression & N.S. & N.S. & N.D. & \\
\hline
\end{tabular}

Abbreviations: AV, Ampulla of Vater; CCA, cholangiocarcinoma; iCCA, intrahepatic CCA; eCCA, extrahepatic CCA; GB, gallbladder; N.D., not determined; N.S., not significant; S., significant. 
\begin{tabular}{l|l} 
Supplementary Table 6 & Anti-ErbB therapies in CCA.
\end{tabular}

\begin{tabular}{|c|c|c|c|c|c|c|c|}
\hline Type & Name & Reversible & Irreversible & EGFR & ErbB2 & ErbB3 & ErbB4 \\
\hline \multicolumn{8}{|l|}{ TKI } \\
\hline & Erlotinib & $\mathrm{x}$ & & $\mathrm{x}$ & & & \\
\hline & Gefitinib & $\mathrm{x}$ & & $\mathrm{X}$ & & & \\
\hline & AEE788 & $\mathrm{x}$ & & $\mathrm{X}$ & $\mathrm{x}$ & & \\
\hline & Lapatinib & $x$ & & $x$ & $x$ & & \\
\hline & Afatinib & & $\mathrm{x}$ & $\mathrm{x}$ & $\mathrm{x}$ & & $\mathrm{x}$ \\
\hline & Dacomitinib & & $\mathrm{x}$ & $\mathrm{x}$ & $\mathrm{x}$ & & $\mathrm{X}$ \\
\hline & AZD9291 & & $\mathrm{X}$ & $x$ & & & \\
\hline & Vandetanib & & & $\mathrm{x}$ & & & \\
\hline & Tyrphostin AG 879 & & & & $\mathrm{X}$ & & \\
\hline & GW2974 & $\mathrm{X}$ & & $\mathrm{X}$ & $\mathrm{X}$ & & \\
\hline & AEE788 & $\mathrm{X}$ & & $\mathrm{X}$ & $\mathrm{X}$ & & \\
\hline \multicolumn{8}{|l|}{ Antibodies } \\
\hline & Cetuximab & & & $\mathrm{X}$ & & & \\
\hline & Panitumumab & & & $X$ & & & \\
\hline & Pertuzumab & & & & $\mathrm{X}$ & & \\
\hline & Trastuzumab & & & & $\mathrm{x}$ & & \\
\hline & Patritumab & & & & & $\mathrm{x}$ & \\
\hline
\end{tabular}


Supplementary Table 7 $\mid$ Clinical trials with anti-EGFR therapies in CCA

\begin{tabular}{|c|c|c|c|c|c|c|c|c|}
\hline Treatment & $\begin{array}{l}\text { Clinical } \\
\text { phase }\end{array}$ & $\begin{array}{l}\text { Number } \\
\text { of } \\
\text { Patients }\end{array}$ & $\begin{array}{l}\text { CR } \\
\text { (\%) }\end{array}$ & $\begin{array}{l}\text { PR } \\
\text { (\%) }\end{array}$ & $\begin{array}{l}\text { ORR } \\
(\%)\end{array}$ & $\begin{array}{l}\text { SD } \\
(\%)\end{array}$ & $\begin{array}{l}\text { Median } \\
\text { overall } \\
\text { survival } \\
\text { (months) }\end{array}$ & Ref. \\
\hline Erlotinib & II & 42 & 0 & 8 & 8 & 43 & 7.5 & (25) \\
\hline Lapatinib & II & 17 & 0 & 0 & 0 & 26 & 5.2 & (45) \\
\hline Erlotinib/ & II & 53 & 0 & 12 & 12 & 51 & 9.9 & (46) \\
\hline Bevacizumab & & & & & & & & \\
\hline $\begin{aligned} & \text { GEMOX } \\
+ & \text { cetuximab }\end{aligned}$ & II & 30 & 10 & 53 & 63 & 17 & 15.2 & (47) \\
\hline GEMOX & III & & & & & & & $(33,48)$ \\
\hline +erlotinib & & 135 & 0 & 30 & 30 & 36 & 9.5 & \\
\hline -erlotinib & & 133 & 2 & 14 & 16 & 51 & 9.5 & \\
\hline $\begin{array}{c}\text { GEMOX } \\
\text { +capeticabine } \\
\text { +panitumumab }\end{array}$ & II & 46 & 2,4 & 31 & 33 & 50 & 10 & (49) \\
\hline $\begin{array}{l}\text { Gemcitabine } \\
\text { +capecitabine } \\
\text { +cetuximab }\end{array}$ & II & 34 & 6 & 12 & 18 & & 15.7 & (50) \\
\hline $\begin{array}{l}\text { Gemcitabine } \\
\text { +irinotecan } \\
\text { +panitumumab }\end{array}$ & II & 35 & 6 & 26 & 74 & 43 & 12.9 & (51) \\
\hline GEMOX +panitumumab & II & 31 & 0 & 45 & 45 & 45 & 20.3 & (52) \\
\hline GEMOX & II & & & & & & & (53) \\
\hline +cetuximab & & 76 & 1 & 17 & 24 & 44 & 11 & \\
\hline -cetuximab & & 74 & 2 & 15 & 23 & 31 & 12.4 & \\
\hline $\begin{array}{l}\text { Sorafenib } \\
\text { +erlotinib }\end{array}$ & II & 34 & 0 & 6 & - & - & 6 & (54) \\
\hline Vandetanib & II & 59 & - & - & 4 & - & 7.6 & (55) \\
\hline $\begin{array}{l}\text { Vandetanib } \\
\text { +Gemcitabine }\end{array}$ & & 58 & - & - & 19 & - & 9.5 & \\
\hline $\begin{array}{l}\text { Gemcitabine } \\
\text { +placebo }\end{array}$ & & 56 & - & - & 14 & - & 10.2 & \\
\hline GEMOX & II & & & & & & & (56) \\
\hline +cetuximab & & 62 & - & 24 & 27 & 55 & 10.6 & \\
\hline - cetuximab & & 60 & - & 15 & 15 & 45 & 9.8 & \\
\hline GEMOX & II & & & & & & & (57) \\
\hline + panitumumab & & 45 & 2 & 24 & 27 & 49 & 9.9 & \\
\hline - panitumumab & & 44 & 2 & 16 & 18 & 50 & 10.2 & \\
\hline $\begin{array}{l}\text { Gemcitabine } \\
\text { +Cisplatine } \\
+ \text { Panitumumab }\end{array}$ & II & 46 & 2 & 30 & - & 41 & 30 & (58) \\
\hline $\begin{array}{c}\text { GEMOX } \\
\text { +pulsatile erlotinib }\end{array}$ & $\mathrm{lb}$ & 17 & 0 & 29 & 29 & 65 & 18 & (59) \\
\hline
\end{tabular}

Abbreviations: GEMOX : gemcitabine + oxaliplatine; CR, complete response; ORR, objective response rate; PR, partial response; $\mathrm{SD}$, stable disease. 


\section{References}

1. Nonomura A, Ohta G, Nakanuma Y, Izumi R, Mizukami Y, Matsubara F, Hayashi M, et al. Simultaneous detection of epidermal growth factor receptor (EGF-R), epidermal growth factor (EGF) and ras p21 in cholangiocarcinoma by an immunocytochemical method. Liver 1988;8:157-166.

2. Lee CS, Pirdas A. Epidermal growth factor receptor immunoreactivity in gallbladder and extrahepatic biliary tract tumours. Pathol Res Pract 1995;191:1087-1091.

3. Ito Y, Takeda T, Sasaki Y, Sakon M, Yamada T, Ishiguro S, Imaoka S, et al. Expression and clinical significance of the erbB family in intrahepatic cholangiocellular carcinoma. Pathol Res Pract 2001;197:95-100.

4. Altimari A, Fiorentino M, Gabusi E, Gruppioni E, Corti B, D'Errico A, Grigioni WF. Investigation of ErbB1 and ErbB2 expression for therapeutic targeting in primary liver tumours. Dig Liver Dis 2003;35:332-338.

5. Jan YY, Yeh TS, Yeh JN, Yang HR, Chen MF. Expression of epidermal growth factor receptor, apomucins, matrix metalloproteinases, and p53 in rat and human cholangiocarcinoma: appraisal of an animal model of cholangiocarcinoma. Ann Surg 2004;240:89-94.

6. Yeh TS, Tseng JH, Chen TC, Liu NJ, Chiu CT, Jan YY, Chen MF. Characterization of intrahepatic cholangiocarcinoma of the intraductal growth-type and its precursor lesions. Hepatology 2005;42:657-664.

7. Nakazawa K, Dobashi Y, Suzuki S, Fujii H, Takeda Y, Ooi A. Amplification and overexpression of c-erbB-2, epidermal growth factor receptor, and c-met in biliary tract cancers. J Pathol 2005;206:356-365.

8. Ogo Y, Nio Y, Yano S, Toga T, Koike M, Hashimoto $\mathrm{K}$, Itakura $\mathrm{M}$, et al. Immunohistochemical expression of HER-1 and HER-2 in extrahepatic biliary carcinoma. Anticancer Res 2006;26:763-770. 
9. Javle MM, Yu J, Khoury T, Chadha KS, lyer RV, Foster J, Kuvshinoff BW, et al. Akt expression may predict favorable prognosis in cholangiocarcinoma. J Gastroenterol Hepatol 2006;21:1744-1751.

10. Kawamoto T, Krishnamurthy S, Tarco E, Trivedi S, Wistuba, II, Li D, Roa I, et al. HER Receptor Family: Novel Candidate for Targeted Therapy for Gallbladder and Extrahepatic Bile Duct Cancer. Gastrointest Cancer Res 2007;1:221-227.

11. Yoshikawa D, Ojima H, Iwasaki M, Hiraoka N, Kosuge T, Kasai S, Hirohashi S, et al. Clinicopathological and prognostic significance of EGFR, VEGF, and HER2 expression in cholangiocarcinoma. Br J Cancer 2008;98:418-425.

12. Kaufman M, Mehrotra B, Limaye S, White S, Fuchs A, Lebowicz Y, Nissel-Horowitz S, et al. EGFR expression in gallbladder carcinoma in North America. Int $\mathrm{J}$ Med Sci 2008;5:285-291.

13. Herberger B, Berger W, Puhalla H, Schmid K, Novak S, Brandstetter A, Pirker C, et al. Simultaneous blockade of the epidermal growth factor receptor/mammalian target of rapamycin pathway by epidermal growth factor receptor inhibitors and rapamycin results in reduced cell growth and survival in biliary tract cancer cells. Mol Cancer Ther 2009;8:1547-1556.

14. Harder J, Waiz O, Otto F, Geissler M, Olschewski M, Weinhold B, Blum HE, et al. EGFR and HER2 expression in advanced biliary tract cancer. World J Gastroenterol $2009 ; 15: 4511-4517$

15. Shafizadeh N, Grenert JP, Sahai V, Kakar S. Epidermal growth factor receptor and HER-2/neu status by immunohistochemistry and fluorescence in situ hybridization in adenocarcinomas of the biliary tree and gallbladder. Hum Pathol 2010;41:485-492.

16. Pignochino Y, Sarotto I, Peraldo-Neia C, Penachioni JY, Cavalloni G, Migliardi G, Casorzo L, et al. Targeting EGFR/HER2 pathways enhances the antiproliferative effect of gemcitabine in biliary tract and gallbladder carcinomas. BMC Cancer 2010;10:631.

17. Zhou Q, Gong Y, Huang F, Lin Q, Zeng B, Li Z, Chen R. Expression levels and significance of nuclear factor-kappaB and epidermal growth factor receptor in 
hepatolithiasis associated with intrahepatic cholangiocarcinoma. Dig Surg 2013;30:309316.

18. Wang W, Zhang J, Zhan X, Lin T, Yang M, Hu J, Han B, et al. SOX4 is associated with poor prognosis in cholangiocarcinoma. Biochem Biophys Res Commun 2014;452:614621.

19. Simbolo M, Fassan M, Ruzzenente A, Mafficini A, Wood LD, Corbo V, Melisi D, et al. Multigene mutational profiling of cholangiocarcinomas identifies actionable molecular subgroups. Oncotarget 2014;5:2839-2852.

20. Yang X, Wang W, Wang C, Wang L, Yang M, Qi M, Su H, et al. Characterization of EGFR family gene aberrations in cholangiocarcinoma. Oncol Rep 2014;32:700-708.

21. Kawamoto T, Ishige K, Thomas M, Yamashita-Kashima Y, Shu S, Ishikura N, Ariizumi S, et al. Overexpression and gene amplification of EGFR, HER2, and HER3 in biliary tract carcinomas, and the possibility for therapy with the HER2-targeting antibody pertuzumab. J Gastroenterol 2015;50:467-479.

22. Sadot E, Simpson AL, Do RK, Gonen M, Shia J, Allen PJ, D'Angelica MI, et al. Cholangiocarcinoma: Correlation between Molecular Profiling and Imaging Phenotypes. PLoS One 2015;10:e0132953.

23. Moon A, Chin S, Kim HK, Kwak JJ, Koh ES, Kim YW, Jang KT. EGFR, COX2, p-AKT expression and PIK3CA mutation in distal extrahepatic bile duct carcinoma. Pathology 2016;48:35-40.

24. Claperon A, Guedj N, Mergey M, Vignjevic D, Desbois-Mouthon C, Boissan M, Saubamea B, et al. Loss of EBP50 stimulates EGFR activity to induce EMT phenotypic features in biliary cancer cells. Oncogene 2012;31:1376-1388.

25. Philip PA, Mahoney MR, Allmer C, Thomas J, Pitot HC, Kim G, Donehower RC, et al. Phase II study of erlotinib in patients with advanced biliary cancer. J Clin Oncol 2006;24:3069-3074. 
26. Gwak GY, Yoon JH, Shin CM, Ahn YJ, Chung JK, Kim YA, Kim TY, et al. Detection of response-predicting mutations in the kinase domain of the epidermal growth factor receptor gene in cholangiocarcinomas. J Cancer Res Clin Oncol 2005;131:649-652.

27. Bekaii-Saab T, Williams N, Plass C, Calero MV, Eng C. A novel mutation in the tyrosine kinase domain of ERBB2 in hepatocellular carcinoma. BMC Cancer 2006;6:278.

28. Leone F, Cavalloni G, Pignochino Y, Sarotto I, Ferraris R, Piacibello W, Venesio T, et al. Somatic mutations of epidermal growth factor receptor in bile duct and gallbladder carcinoma. Clin Cancer Res 2006;12:1680-1685.

29. Sia D, Hoshida Y, Villanueva A, Roayaie S, Ferrer J, Tabak B, Peix J, et al. Integrative molecular analysis of intrahepatic cholangiocarcinoma reveals 2 classes that have different outcomes. Gastroenterology 2013;144:829-840.

30. Li M, Zhang Z, Li X, Ye J, Wu X, Tan Z, Liu C, et al. Whole-exome and targeted gene sequencing of gallbladder carcinoma identifies recurrent mutations in the ErbB pathway. Nat Genet 2014;46:872-876.

31. Jang S, Chun SM, Hong SM, Sung CO, Park H, Kang HJ, Kim KP, et al. High throughput molecular profiling reveals differential mutation patterns in intrahepatic cholangiocarcinomas arising in chronic advanced liver diseases. Mod Pathol 2014;27:731-739.

32. Chang YT, Chang MC, Huang KW, Tung CC, Hsu C, Wong JM. Clinicopathological and prognostic significances of EGFR, KRAS and BRAF mutations in biliary tract carcinomas in Taiwan. J Gastroenterol Hepatol 2014;29:1119-1125.

33. Kim ST, Jang KT, Lee J, Jang HM, Choi HJ, Jang HL, Park SH, et al. Molecular Subgroup Analysis of Clinical Outcomes in a Phase 3 Study of Gemcitabine and Oxaliplatin with or without Erlotinib in Advanced Biliary Tract Cancer. Transl Oncol 2015;8:40-46.

34. Voravud N, Foster CS, Gilbertson JA, Sikora K, Waxman J. Oncogene expression in cholangiocarcinoma and in normal hepatic development. Hum Pathol 1989;20:11631168. 
35. Collier JD, Guo K, Mathew J, May FE, Bennett MK, Corbett IP, Bassendine MF, et al. cerbB-2 oncogene expression in hepatocellular carcinoma and cholangiocarcinoma. $\mathrm{J}$ Hepatol 1992;14:377-380.

36. Brunt EM, Swanson PE. Immunoreactivity for c-erbB-2 oncopeptide in benign and malignant diseases of the liver. Am J Clin Pathol 1992;97:S53-61.

37. Chow NH, Huang SM, Chan SH, Mo LR, Hwang MH, Su WC. Significance of c-erbB-2 expression in normal and neoplastic epithelium of biliary tract. Anticancer Res $1995 ; 15: 1055-1059$.

38. Terada T, Ashida K, Endo K, Horie S, Maeta H, Matsunaga Y, Takashima K, et al. cerbB-2 protein is expressed in hepatolithiasis and cholangiocarcinoma. Histopathology 1998;33:325-331.

39. Suzuki H, Isaji S, Pairojkul C, Uttaravichien T. Comparative clinicopathological study of resected intrahepatic cholangiocarcinoma in northeast Thailand and Japan. $\mathrm{J}$ Hepatobiliary Pancreat Surg 2000;7:206-211.

40. Aishima SI, Taguchi KI, Sugimachi K, Shimada M, Sugimachi K, Tsuneyoshi M. c-erbB-2 and c-Met expression relates to cholangiocarcinogenesis and progression of intrahepatic cholangiocarcinoma. Histopathology 2002;40:269-278.

41. Ukita $\mathrm{Y}$, Kato M, Terada T. Gene amplification and mRNA and protein overexpression of c-erbB-2 (HER-2/neu) in human intrahepatic cholangiocarcinoma as detected by fluorescence in situ hybridization, in situ hybridization, and immunohistochemistry. J Hepatol 2002;36:780-785.

42. Endo K, Yoon BI, Pairojkul C, Demetris AJ, Sirica AE. ERBB-2 overexpression and cyclooxygenase-2 up-regulation in human cholangiocarcinoma and risk conditions. Hepatology 2002;36:439-450.

43. Settakorn J, Kaewpila N, Burns GF, Leong AS. FAT, E-cadherin, beta catenin, HER 2/neu, Ki67 immuno-expression, and histological grade in intrahepatic cholangiocarcinoma. J Clin Pathol 2005;58:1249-1254. 
44. Lee HJ, Chung JY, Hewitt SM, Yu E, Hong SM. HER3 overexpression is a prognostic indicator of extrahepatic cholangiocarcinoma. Virchows Arch 2012;461:521-530.

45. Ramanathan RK, Belani CP, Singh DA, Tanaka M, Lenz HJ, Yen Y, Kindler HL, et al. A phase II study of lapatinib in patients with advanced biliary tree and hepatocellular cancer. Cancer Chemother Pharmacol 2009;64:777-783.

46. Lubner SJ, Mahoney MR, Kolesar JL, Loconte NK, Kim GP, Pitot HC, Philip PA, et al. Report of a multicenter phase II trial testing a combination of biweekly bevacizumab and daily erlotinib in patients with unresectable biliary cancer: a phase II Consortium study. J Clin Oncol 2010;28:3491-3497.

47. Gruenberger B, Schueller J, Heubrandtner U, Wrba F, Tamandl D, Kaczirek K, Roka R, et al. Cetuximab, gemcitabine, and oxaliplatin in patients with unresectable advanced or metastatic biliary tract cancer: a phase 2 study. Lancet Oncol 2010;11:1142-1148.

48. Lee J, Park SH, Chang HM, Kim JS, Choi HJ, Lee MA, Jang JS, et al. Gemcitabine and oxaliplatin with or without erlotinib in advanced biliary-tract cancer: a multicentre, openlabel, randomised, phase 3 study. Lancet Oncol 2012;13:181-188.

49. Jensen LH, Lindebjerg J, Ploen J, Hansen TF, Jakobsen A. Phase II marker-driven trial of panitumumab and chemotherapy in KRAS wild-type biliary tract cancer. Ann Oncol 2012;23:2341-2346.

50. Rubovszky G, Lang I, Ganofszky E, Horvath Z, Juhos E, Nagy T, Szabo E, et al. Cetuximab, gemcitabine and capecitabine in patients with inoperable biliary tract cancer: a phase 2 study. Eur J Cancer 2013;49:3806-3812.

51. Sohal DP, Mykulowycz K, Uehara T, Teitelbaum UR, Damjanov N, Giantonio BJ, Carberry $M$, et al. A phase II trial of gemcitabine, irinotecan and panitumumab in advanced cholangiocarcinoma. Ann Oncol 2013;24:3061-3065.

52. Hezel AF, Noel MS, Allen JN, Abrams TA, Yurgelun M, Faris JE, Goyal L, et al. Phase II study of gemcitabine, oxaliplatin in combination with panitumumab in KRAS wild-type unresectable or metastatic biliary tract and gallbladder cancer. $\mathrm{Br} \mathrm{J}$ Cancer $2014 ; 111: 430-436$. 
53. Malka D, Cervera P, Foulon S, Trarbach T, de la Fouchardiere C, Boucher E, Fartoux L, et al. Gemcitabine and oxaliplatin with or without cetuximab in advanced biliary-tract cancer (BINGO): a randomised, open-label, non-comparative phase 2 trial. Lancet Oncol $2014 ; 15: 819-828$.

54. El-Khoueiry AB, Rankin C, Siegel AB, lqbal S, Gong IY, Micetich KC, Kayaleh OR, et al. S0941: a phase 2 SWOG study of sorafenib and erlotinib in patients with advanced gallbladder carcinoma or cholangiocarcinoma. Br J Cancer 2014;110:882-887.

55. Santoro A, Gebbia V, Pressiani T, Testa A, Personeni N, Arrivas Bajardi E, Foa P, et al. A randomized, multicenter, phase II study of vandetanib monotherapy versus vandetanib in combination with gemcitabine versus gemcitabine plus placebo in subjects with advanced biliary tract cancer: the VanGogh study. Ann Oncol 2015;26:542-547.

56. Chen JS, Hsu C, Chiang NJ, Tsai CS, Tsou HH, Huang SF, Bai LY, et al. A KRAS mutation status-stratified randomized phase II trial of gemcitabine and oxaliplatin alone or in combination with cetuximab in advanced biliary tract cancer. Ann Oncol 2015;26:943-949.

57. Leone F, Marino D, Cereda S, Filippi R, Belli C, Spadi R, Nasti G, et al. Panitumumab in combination with gemcitabine and oxaliplatin does not prolong survival in wild-type KRAS advanced biliary tract cancer: A randomized phase 2 trial (Vecti-BIL study). Cancer 2016;122:574-581.

58. Ferraro D, Goldstein D, O'Connell RL, Zalcberg JR, Sjoquist KM, Tebbutt NC, Grimison P, et al. TACTIC: a multicentre, open-label, single-arm phase II trial of panitumumab, cisplatin, and gemcitabine in biliary tract cancer. Cancer Chemother Pharmacol 2016;78:361-367.

59. Goff LW, Cardin DB, Whisenant JG, Du L, Koyama T, Dahlman KB, Salaria SN, et al. A phase I trial investigating pulsatile erlotinib in combination with gemcitabine and oxaliplatin in advanced biliary tract cancers. Invest New Drugs 2017;35:95-104.

Author names in bold designate shared co-first authorship. 